\title{
Headwater Flow Geochemistry of Mount Everest (Upper Dudh Koshi River, Nepal)
}

\author{
Pierre Chevallier ${ }^{1 *}$, Jean-Luc Seidel' ${ }^{1}$, Jean-Denis Taupin ${ }^{1}$ and Ornella Puschiasis ${ }^{2,3}$ \\ ${ }^{1}$ Laboratoire HydroSciences Montpellier, Centre National de la Recherche Scientifique, Institut de Recherche pour le \\ Développement, Université de Montpellier, Montpellier, France, ${ }^{2}$ Centre d'Etudes en Sciences Sociales sur les Mondes \\ Africains, Américains et Asiatiques, I'Institut National des Langues et Civilisations Orientales, l'Institut de Recherche pour le \\ Développement, Université de Paris, Paris, France, ${ }^{3}$ Centre d'Etudes Himalayennes, Centre National de la Recherche \\ Scientifique, Paris-Villejuif, France
}

The aim of this work, conducted in the upper valley of the Khumbu on the southern part of Mount Everest, is to approach in parallel three topics: (i) the dynamics of the water geochemistry, major ions and trace elements; (ii) the stable water isotopes of precipitation and rivers; and (iii) the water uses by the inhabitants. As in most mountain environments, the Khumbu area is threatened by climate change, which impacts the cryosphere and consequently the people and the landscapes. Moreover, changes in

OPEN ACCESS

Edited by:

Xiuping $\mathrm{Li}$,

Institute of Tibetan Plateau Research (CAS), China

Reviewed by:

Andre Banning,

Ruhr University Bochum, Germany

Yan Bai,

Center for Excellence in Tibetan Plateau Earth Sciences (CAS), China

${ }^{*}$ Correspondence:

Pierre Chevallier

pierre.chevallier@ird.fr

Specialty section:

This article was submitted to Hydrosphere,

a section of the journal

Frontiers in Earth Science

Received: 24 April 2020

Accepted: 28 July 2020

Published: 04 September 2020

Citation:

Chevallier P, Seidel J-L,

Taupin J-D and Puschiasis O (2020) Headwater Flow Geochemistry of Mount Everest (Upper Dudh Koshi River, Nepal). Front. Earth Sci. 8:351. doi: 10.3389/feart.2020.00351 water use are also related to new needs stemming from tourism, which strongly affect local livelihood. For the first two topics, new results are presented. They provide details on the global chemical quality of the river water and show how certain elements are seasonally influenced and how other elements allow us to distinguish the water origins within the study zone. Beside the use of stable isotopes to determine mainly the origin of the water flow in the rivers, the isotopic patterns confirm the double climatic influence of the westerly fluxes in the winter season and of the Asian monsoon in the summer season. Regarding water use, the study does not conclude on the potability of the water resource, because microbiologic and organic components have not been investigated; however it confirms that the chemical quality is good. In conclusion, we attempt to predict the future of the geochemistry patterns submitted to the double pressure of climate change and the surge in tourism.

Keywords: major ions, trace elements, stable isotopes, precipitation, river flow, water use, Central Himalaya

\section{INTRODUCTION}

The future of the cryosphere (glacier and snow cover) in the Hindu Kush Himalaya high mountains is a major concern (Pörtner et al., 2019; Wester et al., 2019); it is threatened not only by global warming due to greenhouse gas emissions, but also by local air pollution due to the atmospheric brown cloud, and especially the transportation and deposition of black carbon aerosol (Bonasoni et al., 2010; Kaspari et al., 2011; Jacobi et al., 2015) from human activities in the densely inhabited regions of the south and southwest of the Central Himalaya mountain range as well as the rapid increase of tourist activity (Jacquemet, 2018).

In this context, the Paprika and Preshine projects (see section "Funding") joined the efforts of Nepalese, French, and Italian research teams (see section "Acknowledgments") to explore the 
impact of these anthropogenic constraints on the water cycle dynamics in the Dudh Koshi River Basin (Figure 1) on the south side of Mount Everest $(8847 \mathrm{~m})$. Several reasons justified the choice of this study zone that is characterized by two confluent watercourses, the Imja River and the Khumbu River, respectively, originating from the southern and western faces of the main range of Mount Everest and its satellite summits.

Among these reasons, the following are particularly important in the context of this article:

- Relative facility of access with the Everest Base Camp Trail;

- Settlements at high altitude (above $3500 \mathrm{~m}$ ) where inhabitants are facing a wide range of changes beside climatic one as a more tourism-centered economy involving integration to global markets, agropastoral and lifestyles changes, and new migration patterns (Puschiasis, 2019);

- Presence of a high-altitude scientific laboratory, the Pyramid of Lobuche $(5050 \mathrm{~m})$, administrated by the Italian Ev-K2/CNR association in agreement with the Nepalese Academy of Science and Technology (NAST).

In this framework, a working task of the Paprika and Preshine projects has been devoted to the identification of water resources and the perception of this held by the local inhabitants. In the preliminary exchanges with the scientists of the Paprika and Preshine projects, the Khumbu valley inhabitants manifested a deep concern regarding their water resource and its future. They were acutely aware that climate and economic changes will have a direct impact on the environment in which they live. As a consequence, it appears as a necessity to also aboard the climate processes and the water balance through the geochemical angle, even though this was not the primary route chosen for these projects.

The village of Pangboche, which includes several settlements, was chosen as the most convenient. The main settlement is located at an elevation of approximately $3950 \mathrm{~m}$ on the right bank of the Imja River, $4 \mathrm{~km}$ after the confluence of its two main branches: the Khumbu River flowing from the north and the Upper Imja River flowing from the west. An important concern of the local population is the future of the water resources, not only in quantity, but also in quality. Considering the latter point, it was also stated that the water quality could be a substantial indicator of the water flow processes, especially regarding the different origins of these flows: glacier melt, snowmelt, groundwater, or direct surface flow. The emergence of deep water is not documented, but is unlikely or negligible. This hypothesis is supported by the absence of local hot springs and by the water temperatures observed in springs or slope streams, which are directly influenced by air temperature (Figure 2), confirming a surface or a shallow origin.

During the past decade, geochemistry studies have been conducted of the Himalaya water flows (e.g., Jeelani et al., 2011; Ghezzi et al., 2017), but no study has been undertaken in the context of very high altitudes covering dynamically an entire year. This issue underlines the exploratory character of the current study, which, however, does not aim to address all the questions raised in this exceptional framework.

Numerous isotopic precipitation and river studies have been carried out in Himalaya at the local or regional scale in the past few years (Garzione et al., 2000; Wen et al., 2012; Jeelani et al., 2013, 2017; Balestrini et al., 2014, 2016; He and Richards, 2016; Ren et al., 2017; Florea et al., 2017; Jeelani and Deshpande, 2017; Guo et al., 2017; Li and Garzione, 2017; Kumar et al., 2018; Verma et al., 2018; Shen and Poulsen, 2019; Singh et al., 2019). The main aim of these studies was to link the isotopic variability recorded in precipitation to climate parameters and air mass circulation and the transfer of this isotopic signal through the global and complex altitudinal hydrosystem from glaciers to tropical valleys. Regional precipitation studies of the southern external border of Himalaya (Jeelani and Deshpande, 2017) from Kashmir (western Himalaya) to Assam (eastern Himalaya), or of the whole Tibetan Plateau (Li and Garzione, 2017), showed that the isotopic variation observed in precipitation across the Himalayas conforms to the regional repartition of the two main moisture sources: the westerly fluxes and Asian monsoon. Local studies of precipitation isotopes were carried out in central Nepal, Kathmandu, and the north of Kathmandu (Wen et al., 2012) as well as in the Khumbu Valley at the Pyramid Laboratory (Balestrini et al., 2014, 2016).

The current article aims to present, analyze and discuss, on the one hand, the geochemical behavior of the water flows used by the inhabitants of Pangboche for their activities, during the year 2011, exploring the conductivity, $\mathrm{pH}$, major ions, and trace elements dissolved in the water; and, on the other hand, the water-stable isotopes in the precipitation and river flows of the Khumbu area, during the period from November 2014 to May 2017. The article aims to link these data to the water origins and seasonal variability in the context of global change.

\section{STUDY AREA AND METHODS}

\section{Study Area}

The climate of the study area is dominated from June to September by monsoon dynamics (Wang, 2006; Bookhagen and Burbank, 2010; Immerzeel et al., 2010; Turner and Annamalai, 2012), but winter and pre-monsoon precipitations can occur from December to April due to the Western Disturbances, which are part of the westerlies entry, originating from the Mediterranean region (Pisharoty and Desai, 1956; Madhura et al., 2015).

Above $5000 \mathrm{~m}$ in general, and lower during the winter, satellite imagery shows that the snow cover can be wide; however, the difficulty of monitoring snowfall in high mountains (Sevruk, 1989; Tahir et al., 2011) does not allow us to quantify precisely the volume of snowfall in the study area. Recent studies have explored the spatial distribution of precipitation in this area (Savéan et al., 2015; Gonga-Saholiariliva et al., 2016; Eeckman et al., 2017; Mimeau et al., 2019). They roughly show, beside a large local heterogeneity mainly due to the steep relief, the valley orientation and the slope aspect, a positive gradient with the 

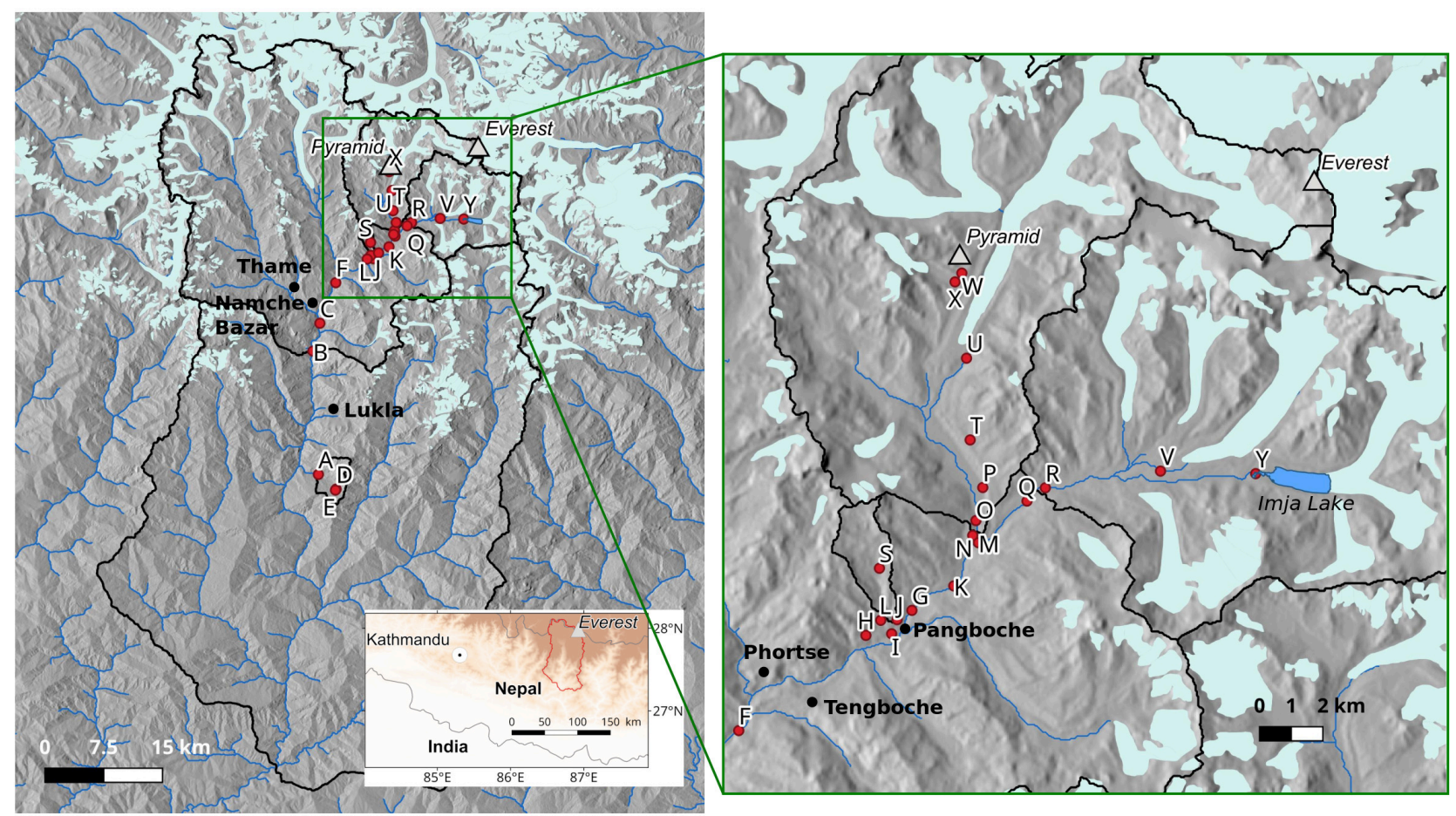

FIGURE 1 | Bottom left: location of the Dudh Koshi River basin (red line). Left: Dudh Koshi River basin and sub-basins, southern Mount Everest. Right: details of the Upper Khumbu and Imja area. The red dots represent the sampling points. The labels refer to Table 1. Sources: for relief, digital elevation model based on Spot-HRS images with a 40-m resolution (Gardelle et al., 2013); for glacier extension, Randolf Glacier Inventory (RGI Consortium 2017).

altitude until a peak of annual precipitation between 2500 and $3200 \mathrm{~m}$ and a negative one above.

The geology of the southern area of Mount Everest has been detailed by Bortolami (1998) and Searle et al. (2003). It is dominated by Precambrian-Early Paleozoic sillimanite gneisses in the high faces, which alternate in some places with intrusive Miocene leucogranites. The highest zone (Everest, Lhotse), above $6500 \mathrm{~m}$, presents Ordovician shale series and limestone layers. Except for those slopes covered by glaciers or rock glaciers, the valley slopes and valley bottoms are mainly composed of fluvio-glacial deposits and debris, with the presence of moraines of different levels and ages. According to Bortolami (1998), the composition of the rocks leads to a low weathering and a low impact on the chemical composition of the flows. The same author notes that the aquifers located in the debris material have a high porosity. Their thicknesses are largely unknown. By contrast, the fissured rocks, which constitute the bed rock, are generally impermeable. A few other studies are devoted to groundwater storage in the Himalayas. Although their findings are not very helpful with regard to the geological characteristics (Dongol et al., 2005; Jeelani, 2008) or the scale of the approach used (Andermann et al., 2012), these studies highlight a notable contribution of snow and glacier melt to groundwater. Andermann et al. (2012) assess the storing capacity of the whole Dudh Koshi basin $\left(3700 \mathrm{~km}^{2}\right)$ to be approximately $300 \mathrm{~mm}$, i.e., less than $20 \%$ of the average annual discharge, which represents a low impact of the groundwater in our study area, considering that most of the reservoirs are very likely concentrated in the bottom material of the middle and low elevations. Other authors, including Nepal et al. (2014), Savéan et al. (2015), and Eeckman et al. (2019), consider in their modeling approaches that the volume stored over a long period in groundwater reservoirs is negligible.

\section{Water Resources for Local Population}

The Khumbu zone (Figure 1) encompasses an area of approximately $1100 \mathrm{~km}^{2}$ along the border between Nepal and the Tibet Autonomous Region of China. It is included in the Nepalese administrative division of the Solu-Khumbu district. The area is divided into three major distinct valleys-Imja Valley, Dudh Koshi Valley, and Bhote Khosi Valley-forming a U-shape, a testimonial to the glacial erosion and draining of the main rivers in the region. The Dudh Koshi first meets the Imja Khola on the eastern side of the region, and it then meets the Bhote Koshi before running out of Khumbu toward the south into a deep gorge. Khumbu settlements span elevations from $2805 \mathrm{~m}$ (Jorsalle) to $5170 \mathrm{~m}$ (Gorak Shep). The villages are located extensively on the rare alluvial terraces, hanging valleys, and amphitheater slumps and comprise mostly south- and north-facing slopes. Khumbu corresponds to the former Village Development Committees (VDCs, before administrative restructuring in 2017) of Khumjung and Namche hosting approximately 3500 residents belonging mostly to the 


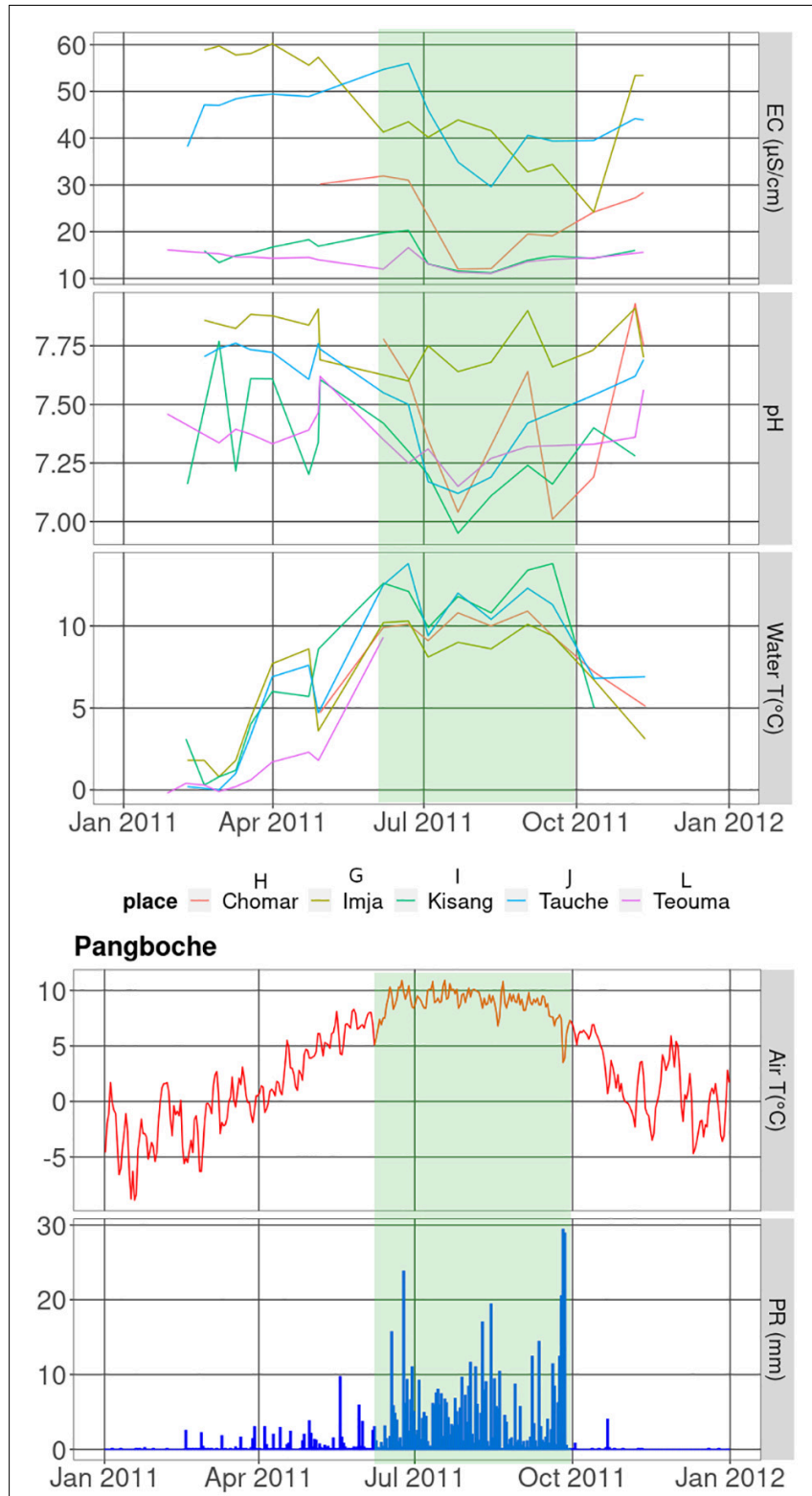

FIGURE 2 | Year 2011. Up: electrical conductivity (EC), pH and water temperature $(T)$ at the five sampling points around Pangboche ( 4000 m). Down: daily temperature (T) and precipitation (PR) at Pangboche weather station. The monsoon season (JJAS) is highlighted in green.

Sherpa ethnic group with a growing number of non-Sherpa residents (Rais, Tamangs, Magar, and Bahun-Chhetri). With the establishment of the Sagarmatha National Park (SNP) in 1976 and its designation as a UNESCO World Heritage Site in 1979, the economy of the region has shifted to a more tourism-centered form (Spoon, 2011). The number of visitors to the SNP increased to 45,000 in 2017 (Jacquemet, 2018) leading to an important trekking and expedition tourism hub, including the popular trekking route to Mount Everest Base Camp.
All these territorial and economic mutations have led to profound changes in water resources, increasing needs previously limited to domestic (drinking water, cooking, personal hygiene), agricultural (irrigation of barley), and religious purposes (waterdriven prayer wheels, water spirit shrine) (Aubriot et al., 2019). Water is taken directly from springs or small streams flowing through the settlements or channeled by pipes to houses, since large rivers are not the primary source of water for villagers (McDowell et al., 2012). In Pangboche village, changes appeared some 20 years ago with the installation of running water supplying guest houses, a bottled-water manufacturing plant in 2003, and a micro-hydroelectric plant in 2004 (Puschiasis, 2015). Water has become a "commodity" (André-Lamat, 2017) with a proliferation of uses for tourism (shower, flushing toilets, bottled water) and for electrification. Khumbu inhabitants have become highly dependent on reliable water supply systems to respond to the new types of usages, which is key to local development. Nevertheless, there is a lack of a proper management system at a regional level to reduce the pressure on water resources.

\section{Methods of Sampling and Analysis}

Labels A to Y refer to the sampling points shown in Figure 1 and described in Table 1. They are ordered by altitude from bottom to top.

\section{Conductivity, Major, and Trace Elements}

Temperature, $\mathrm{pH}$, and electrical conductivity $\left(\mathrm{T}_{\text {ref }}=25^{\circ} \mathrm{C}\right)$ were measured in the field, using a portable $\mathrm{pH}$ meter and conductivity meter (WTW $\left.3210 \mathrm{i}^{\circledR}\right)$. Water samples $(125 \mathrm{~mL}$ ) were filtered in the field with a PP syringe and Durapore ${ }^{\circledR}$ membrane $(0.22 \mu \mathrm{m})$ and stored in acid-washed HDPE bottles. Aliquots for major cations and trace elements were acidified with ultrapure $\mathrm{HNO}_{3}\left(1 \%\right.$ v/v). Samples were stored at $4^{\circ} \mathrm{C}$ before reaching Montpellier for analysis.

Five sites in the surroundings of Pangboche village were selected for the water sampling $(G, H, I, J, L)$ :

- The G point on the Imja River represents the reference site for the main river after the confluence of the Khumbu branch and the Imja branch. These catchments include, on the one hand, the large glaciers of the south side of the Everest Range and, on the other hand, the Imja moraine lake, which concentrates the melting runoff from the majority of the glaciers of the upper Imja Valley.

- The Tauche point $(\mathrm{J})$ on the east stream of the southern slope of the Tauche Peak $(6542 \mathrm{~m})$. This watercourse collects the melt flow from the very small glacier located on the peak summit.

- The Teouma (L) and Kisang (I) points on the central stream flow do not receive water of glacial origin. Because this watercourse flows through the village of Pangboche, the first point was chosen upstream and the second downstream from the village in order to analyze how the water quality of the stream is influenced by the village.

- The Chomar $(\mathrm{H})$ source on the west side of Pangboche was also sampled, because its water was drawn and bottled 
TABLE 1 | Main characteristics of the sampling points (ordered by altitude).

\begin{tabular}{|c|c|c|c|c|c|c|c|}
\hline \multirow[t]{2}{*}{ Name (+) } & \multirow[t]{2}{*}{ Label (++) } & \multicolumn{3}{|c|}{ Coordinates } & \multirow[t]{2}{*}{ Data type $\left(^{*}\right)$} & \multirow[t]{2}{*}{ Sample $\left(^{* \star}\right)$} & \multirow[t]{2}{*}{ Glaciers $\left({ }^{* \star *}\right)$} \\
\hline & & Longitude & Latitude & Altitude (m) & & & \\
\hline Kharikhola & $A$ & $86^{\circ} 43^{\prime \prime} 16^{\prime \prime}$ & $27^{\circ} 36^{\prime} 22^{\prime \prime}$ & 1981 & $\mathrm{R}$ & IS & $\mathrm{N}$ \\
\hline Phakding & $\mathrm{B}$ & $86^{\circ} 42^{\prime} 47^{\prime \prime}$ & $27^{\circ} 44^{\prime} 53^{\prime \prime}$ & 2620 & $R$ & IS & Y \\
\hline Jorsalle & C & $86^{\circ} 43^{\prime} 19^{\prime \prime}$ & $27^{\circ} 46^{\prime} 48^{\prime \prime}$ & 2850 & $R$ & IS & Y \\
\hline Pangom river & $\mathrm{D}$ & $86^{\circ} 44^{\prime} 38^{\prime \prime}$ & $27^{\circ} 35^{\prime} 24^{\prime \prime}$ & 2880 & $\mathrm{R}$ & IS & $\mathrm{N}$ \\
\hline Pangom village & $E$ & $86^{\circ} 44^{\prime} 35^{\prime \prime}$ & $27^{\circ} 35^{\prime} 17^{\prime \prime}$ & 2890 & $P$ & IS & - \\
\hline Phuki Tenga & $\mathrm{F}$ & $86^{\circ} 44^{\prime} 35^{\prime \prime}$ & $27^{\circ} 49^{\prime} 37^{\prime \prime}$ & 3200 & $\mathrm{R}$ & IS & Y \\
\hline Pangboche-Imja & $G$ & $86^{\circ} 47^{\prime} 53^{\prime \prime}$ & $27^{\circ} 51^{\prime} 40^{\prime \prime}$ & 3917 & $R$ & MT IS & Y \\
\hline Pangboche-Chomar & $\mathrm{H}$ & $86^{\circ} 46^{\prime} 59^{\prime \prime}$ & $27^{\circ} 51^{\prime} 14^{\prime \prime}$ & 3930 & R \& bottle & MT & $\mathrm{N}$ \\
\hline Pangboche-Kisang & I & $86^{\circ} 47^{\prime} 31^{\prime \prime}$ & $27^{\circ} 51^{\prime} 18^{\prime \prime}$ & 3971 & R & MT & $N$ \\
\hline Pangboche-Tauche & $J$ & $86^{\circ} 47^{\prime} 35^{\prime \prime}$ & $27^{\circ} 51^{\prime} 32^{\prime \prime}$ & 4005 & $\mathrm{R}$ & MT & S \\
\hline Shomare & $\mathrm{K}$ & $86^{\circ} 48^{\prime} 40^{\prime \prime}$ & $27^{\circ} 52^{\prime} 5^{\prime \prime}$ & 4021 & $\mathrm{R}$ & IS & $\mathrm{N}$ \\
\hline Pangboche-Teouma & $L$ & $86^{\circ} 47^{\prime} 17^{\prime \prime}$ & $27^{\circ} 51^{\prime} 32^{\prime \prime}$ & 4148 & $\mathrm{R}$ & MT IS & $\mathrm{N}$ \\
\hline Imja confluence & $M$ & $86^{\circ} 49^{\prime} 08^{\prime \prime}$ & $27^{\circ} 52^{\prime} 52^{\prime \prime}$ & 4172 & $\mathrm{R}$ & $\mathrm{CP}$ & Y \\
\hline Khumbu confluence & $N$ & $86^{\circ} 49^{\prime} 05^{\prime \prime}$ & $27^{\circ} 52^{\prime} 59^{\prime \prime}$ & 4172 & $\mathrm{R}$ & $\mathrm{CP}$ & Y \\
\hline Pheriche hydro & $\mathrm{O}$ & $86^{\circ} 49^{\prime} 08^{\prime \prime}$ & $27^{\circ} 53^{\prime} 13^{\prime \prime}$ & 4216 & $\mathrm{R}$ & IS & Y \\
\hline Pheriche village & $\mathrm{P}$ & $86^{\circ} 49^{\prime} 16^{\prime \prime}$ & $27^{\circ} 53^{\prime} 46^{\prime \prime}$ & 4260 & PR & MT IS & Y \\
\hline Dingboche village & Q & $86^{\circ} 50^{\prime} 06^{\prime \prime}$ & $27^{\circ} 53^{\prime} 35^{\prime \prime}$ & 4370 & $\mathrm{R}$ & IS & Y \\
\hline Dingboche hydro & $\mathrm{R}$ & $86^{\circ} 50^{\prime} 28^{\prime \prime}$ & $27^{\circ} 53^{\prime} 46^{\prime \prime}$ & 4372 & $\mathrm{R}$ & IS & Y \\
\hline Tauche Kharka & S & $86^{\circ} 47^{\prime} 17^{\prime \prime}$ & $27^{\circ} 52^{\prime} 23^{\prime \prime}$ & 4405 & $R$ & IS & S \\
\hline Phulung Kharka & $\mathrm{T}$ & $86^{\circ} 49^{\prime} 01^{\prime \prime}$ & $27^{\circ} 54^{\prime} 36^{\prime \prime}$ & 4504 & $R$ & IS & $S$ \\
\hline Tukla & $U$ & $86^{\circ} 48^{\prime} 54^{\prime \prime}$ & $27^{\circ} 55^{\prime} 59^{\prime \prime}$ & 4700 & $R$ & IS & Y \\
\hline Chukung & $\mathrm{V}$ & $86^{\circ} 52^{\prime} 41^{\prime \prime}$ & $27^{\circ} 54^{\prime} 04^{\prime \prime}$ & 4752 & $R$ & $\mathrm{CP}$ & Y \\
\hline Lobuche river & W & $86^{\circ} 48^{\prime} 50^{\prime \prime}$ & $27^{\circ} 57^{\prime} 25^{\prime \prime}$ & 4840 & $\mathrm{R}$ & IS & Y \\
\hline Lobuche spring & $x$ & $86^{\circ} 48^{\prime} 43^{\prime \prime}$ & $27^{\circ} 57^{\prime} 18^{\prime \prime}$ & 4935 & $\mathrm{R}$ & IS & S \\
\hline Imja Lake & Y & $86^{\circ} 54^{\prime} 29^{\prime \prime}$ & $27^{\circ} 54^{\prime} 00^{\prime \prime}$ & 5001 & $\mathrm{R}$ & MT & Y \\
\hline
\end{tabular}

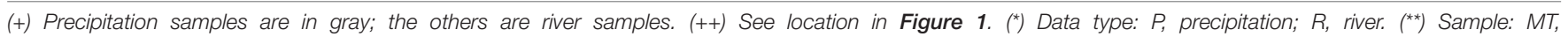
major/trace + conductivity/pH; IS = isotopes; $C P=$ only conductivity/pH. $\left.{ }^{* \star *}\right)$ Glacier: $N=$ no; $Y=$ yes; $S=$ not significant.

in 2011 by a small company to be sold to tourists under the brand name of "Namaste Sabina Tabuche Beiu." After 2013, the company no longer produced bottled water for unknown reasons.

The water flows were sampled 18 times between February and November 2011 following the complete annual cycle (Figure 2). A total of 12 samplings benefited from a complete protocol (64 samples) and 6 more samplings, in winter and autumn, from measurements of electrical conductivity and $\mathrm{pH}$ only.

Two complementary water samples were collected in June 2012 in Imja Lake (Y) and a rainfall reference was taken in the settlement of Pheriche (P). In addition, several measurements of electrical conductivity were carried out in different watercourses within the Imja River basin.

Chemical analyses were performed at the HydroSciences water chemistry laboratory in Montpellier (France). Total alkalinity was measured by acid titration with $\mathrm{HCl} 0.01 \mathrm{~N}$ (Gran method). Major ions $\left(\mathrm{Cl}^{-}, \mathrm{NO}_{3}{ }^{-}, \mathrm{SO}_{4}{ }^{2-}, \mathrm{Ca}^{2+}\right.$, $\mathrm{Mg}^{2+}, \mathrm{Na}^{+}$, and $\mathrm{K}^{+}$) were analyzed by ionic chromatography (Dionex ICS 1000). The precision error was $< \pm 5 \%$. Trace elements ( $\mathrm{Li}, \mathrm{B}, \mathrm{Al}, \mathrm{Si}, \mathrm{Ti}, \mathrm{V}, \mathrm{Cr}, \mathrm{Mn}, \mathrm{Fe}, \mathrm{Co}, \mathrm{Ni}, \mathrm{Cu}, \mathrm{Zn}$, As, $\mathrm{Rb}, \mathrm{Sr}, \mathrm{Mo}, \mathrm{Cd}, \mathrm{Cs}, \mathrm{Ba}, \mathrm{Pb}$, and $\mathrm{U}$ ) were analyzed with
Q-ICPMS (X series2 Thermo Scientific ${ }^{\circledR}$ ) on the AETE (Analyse des Elements en Trace dans l'Environnement) technical platform of Montpellier University. The precision error was $< \pm 8 \%$.

\section{Stable Isotopes}

Six sampling campaigns in rivers located between $1985 \mathrm{~m}$ (Kharikola, label A) and $5000 \mathrm{~m}$ (foot of glaciers, X, Y) were carried out (November to December 2014, November 2015, November 2016, March 2015, May 2016, May 2017).

In addition, during the study interval from November 2014 to December 2016, monthly rainfall was collected at Pangom $(2890 \mathrm{~m}, \mathrm{E})$ using a homemade rain gage with an $80-\mathrm{cm}^{2}$ cross-section in a $5-\mathrm{L}$ plastic tank inside an isotherm box, which was linked to the gage with a flexible pipe and hermetically sealed to avoid direct evaporation.

The rainfall and river samples were stored in amber glass bottles $(25 \mathrm{~mL})$ with conical plugs and transported in shaded conditions to the laboratory in Montpellier.

Water-stable isotopes were measured with an Isoprime ${ }^{\circledR}$ mass spectrometer on the LAMA platform of HydroSciences Montpellier (LAboratoire Mutualisé d'Analyse des isotopes stables de l'eau). The oxygen isotopic composition was measured after 
equilibration of $200 \mu \mathrm{L}$ of water with $\mathrm{CO}_{2}$ via the dual-inlet technique, with an overall precision of $\pm 0.06 \%$. Deuterium was measured by continuous-flow using a Eurovector Pyr$\mathrm{OH}^{\circledR}$ elemental analyzer converting $0.5-\mu \mathrm{L}$ injections of water to $\mathrm{H}_{2}$ on $\mathrm{Cr}$ powder at $1070^{\circ} \mathrm{C}$, with an overall precision of $\pm 0.6 \%$.

Water isotopic compositions are reported as $\delta^{18} \mathrm{O}$ and $\delta^{2} \mathrm{H}$ on the V-SMOW scale.

\section{RESULTS}

\section{Electrical Conductivity and $\mathrm{pH}$}

Figure 2 shows the dynamics of the electrical conductivity and $\mathrm{pH}$ during the year 2011 at the five measurement points $(\mathrm{G}, \mathrm{H}, \mathrm{I}$, $\mathrm{J}, \mathrm{L}$ ) of the Pangboche area.

Regarding electrical conductivity, the absolute values are below $60 \mu \mathrm{S} / \mathrm{cm}$. These very low values indicate the slight level of mineralization of the flows. Specifically, the five sites present two main behaviors: (i) Kisang and Teouma located on the same watercourse have an almost identical and constant extremely low conductivity during the year (approximately $20 \mu \mathrm{S} / \mathrm{cm}$ ), (ii) for Tauche and Imja the values are 2-3 times higher, with a slight decrease during and shortly after the monsoon (July-October), meaning that the increasing runoff generates a dilution effect. The Chomar site fits between the two, with a decrease during the monsoon season.

The $\mathrm{pH}$ varies between 7 and 8, except for PangbocheChomar bottled drinking water (8.6) and for the rain sample (6.8). The different sites present a short-term variability from date to date. However, two main behaviors can be observed: (i) for the slope water courses (Tauche, Kisang, Teouma, and Chomar), the amplitude of the short-term variability reaches 0.5 and a relative dilution effect appears during the monsoon; (ii) the valley river (Imja) has an almost stable $\mathrm{pH}$ value $(\approx 7.8)$ during the course of the year, but higher than the $\mathrm{pH}$ of the slope water courses.

\section{Major lons}

The following ranges in concentration were shown by the major cations and anions: $\mathrm{Ca}^{2+}(1.1-11.1 \mathrm{mg} / \mathrm{L}), \mathrm{Mg}^{2+}(0.1-$ $0.7 \mathrm{mg} / \mathrm{L}), \mathrm{Na}^{+}(0.4-1.8 \mathrm{mg} / \mathrm{L}), \mathrm{K}^{+}(0.2-1.3 \mathrm{mg} / \mathrm{L}), \mathrm{HCO}_{3}{ }^{-}$ (5.1-32.3 mg/L), $\mathrm{SO}_{4}{ }^{2-}(0.4-14.5 \mathrm{mg} / \mathrm{L}), \mathrm{NO}_{3}{ }^{-}(0.1-1.5 \mathrm{mg} / \mathrm{L})$, $\mathrm{Cl}^{-}(0.1-0.6 \mathrm{mg} / \mathrm{L})$. Silica ranges from 1.3 to $20.8 \mathrm{mg} / \mathrm{L}$. Average concentrations of major ions are reported in Table 2. The Piper diagram for major cations and anions (Figure 3 and Table 2) shows variations in the chemical composition of the surface waters, which is dominated by $\mathrm{Ca}^{2+}$ and $\mathrm{HCO}_{3}{ }^{-}$. The waters are mainly of $\mathrm{Ca}^{+}-\mathrm{Mg}^{+}-\mathrm{HCO}_{3}{ }^{-}$type. Waters influenced by glacier melt (Tauche and Imja sites) exhibit an enrichment in $\mathrm{SO}_{4}{ }^{2-}$, particularly for the Tauche site during the monsoon season. $\mathrm{Ca}^{2+}$ is the dominant cation contributing more than $70 \%$ to the cation budget, followed by $\mathrm{Na}^{+}(<20 \%)$ and $\mathrm{Mg}^{2+}$ $(<10 \%)$. In Kisang waters and to a less extent in Teouma waters, before the monsoon season, $\mathrm{Na}^{+}$is the dominant cation. $\mathrm{Cl}^{-}$and $\mathrm{NO}_{3}{ }^{-}$concentrations are very low, $<0.6 \mathrm{mg} / \mathrm{L}$

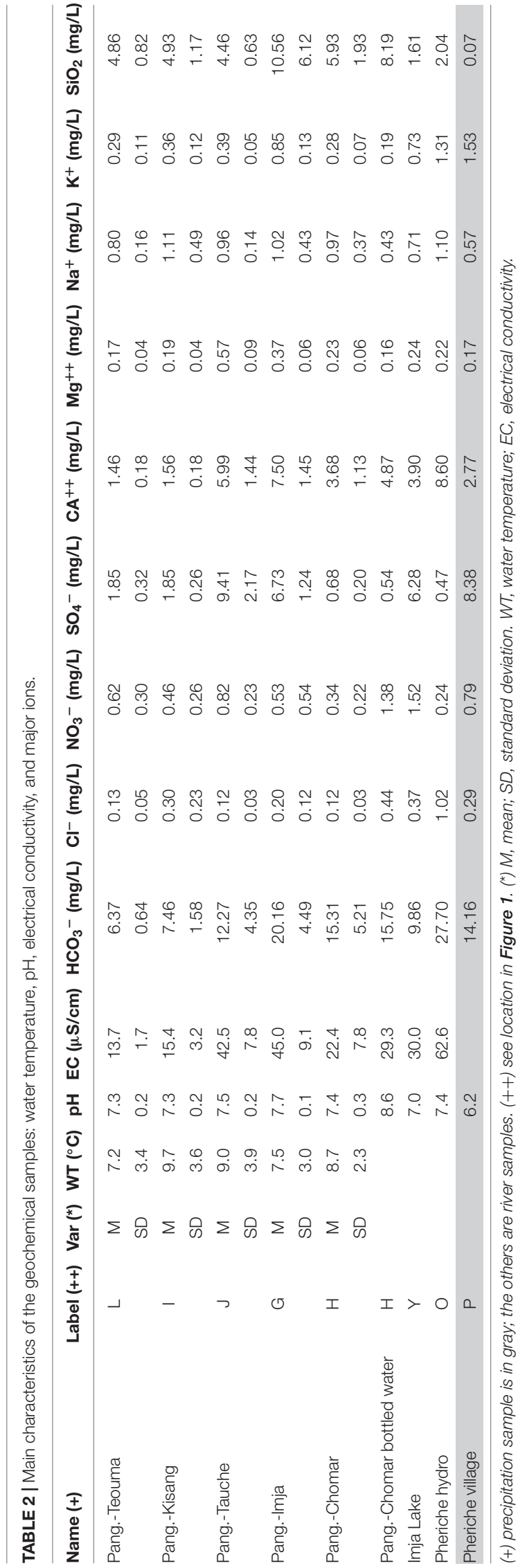




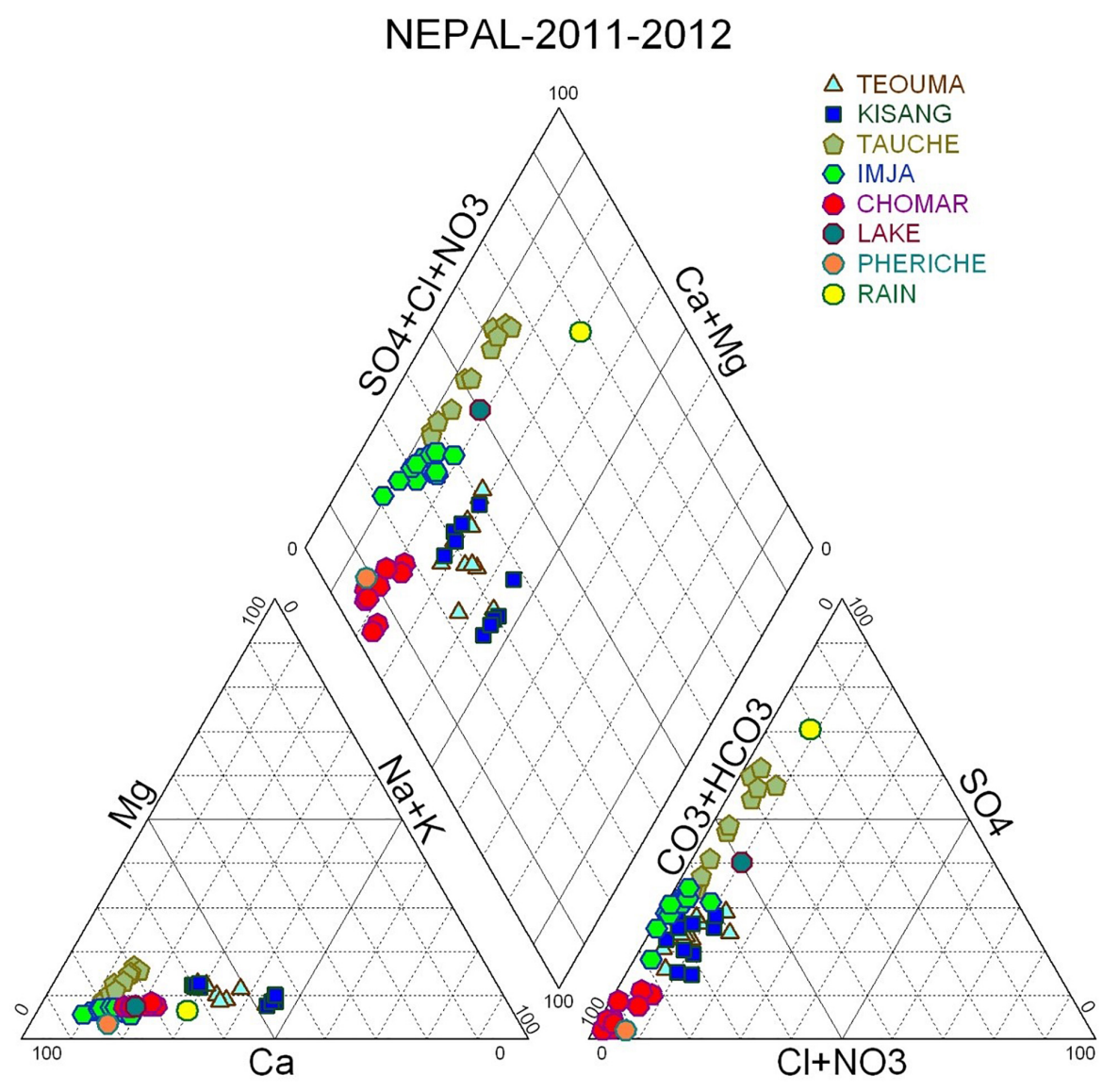

FIGURE 3 | Piper diagram of the major ions in the collected samples.

and $<1.5 \mathrm{mg} / \mathrm{L}$, respectively. The $\mathrm{HCO}_{3}{ }^{-}$contribution to the anion budget ranges between 60 and $90 \%$, except for Tauche water during the monsoon season, which evolves to a $\mathrm{Ca}^{+}-\mathrm{Mg}^{+}-\mathrm{SO}_{4}{ }^{2-}$ type. The origin of sulfates is found in sulfide oxidation via glacier runoff, as suggested by Hodson et al. (2002), because no anhydrite or gypsum have been identified in the region. The plot of $\mathrm{Ca}^{+}+\mathrm{Mg}^{+}+\mathrm{Na}^{+}$versus $\mathrm{HCO}_{3}{ }^{-}+\mathrm{SO}_{4}{ }^{2-}$ from all the waters shows that most of the samples lie close to the 1:1 line, indicating the dissolution of calcite, dolomite, silicates, and sulfides (Figure 4 ) as suggested by Crespo et al. (2017).

For all major elements, including $\mathrm{SiO}_{2}$, the temporal evolution of the concentrations displays a dilution effect during the monsoon season, except for the Imja site where an increase in the concentration of all the major elements occurs during the same season, especially in August 2011, which corresponds to the maximum glacier melt. This enrichment demonstrates that the glaciated catchment undergoes more intense chemical weathering taking place beneath the glacier than catchments that do not have a glacier because the $\mathrm{CO}_{2}$ dissolved in the proglacial zone with the aerated flow conditions characteristic of the meltwater environments may promote chemical weathering by maintaining the acid potential of the water (Reynolds and Johnson, 1972) in Singh and Hasnain (1998).

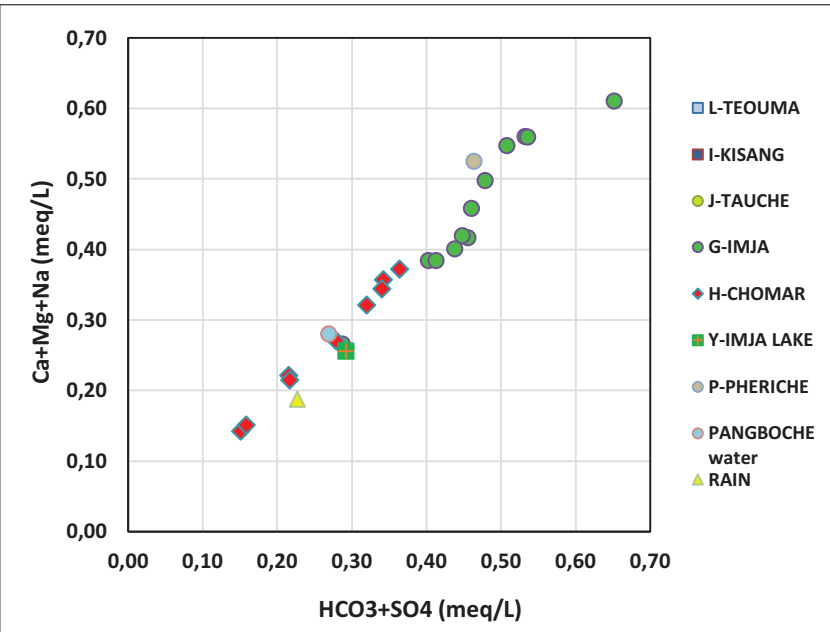

FIGURE $4 \mid \mathrm{Ca}+\mathrm{Mg}+\mathrm{Na}$ versus $\mathrm{HCO}_{3}+\mathrm{SO}_{4}(\mathrm{meq} / \mathrm{L})$.

\section{Trace Elements}

Average concentrations for measured trace elements are presented in Table 3. Dissolved trace elements such as Li, B, $\mathrm{Ni}, \mathrm{Zn}, \mathrm{Cu}, \mathrm{Rb}, \mathrm{Sr}, \mathrm{Ba}$, and $\mathrm{U}$ show a dilution effect during the 
monsoon season at the Teouma, Kisang, Tauche, and Chomar sites whereas the Imja site in the same season exhibits, except for boron, a high concentration increase, by a factor of 10-100, as shown, for example, for rubidium (Figure 5). The origin of this increase can be found in the glacier melt enriched in subglacial material leached by the heavy rain during the monsoon. This phenomenon underlines the integrating power of the Imja Khola River. On the other hand, $\mathrm{Al}, \mathrm{Ti}, \mathrm{Fe}$, and $\mathrm{Mn}$ to a lesser extent increase in all the sites during the monsoon season. In comparison with the Upper Mustang rivers in the western region of Nepal Himalaya (Ghezzi et al., 2017), the concentrations are elevated, from 5 to $6600 \mu \mathrm{g} / \mathrm{L}$ for $\mathrm{Al}$, from 0.5 to $485 \mu \mathrm{g} / \mathrm{L}$ for $\mathrm{Ti}$, from 5 to $7130 \mu \mathrm{g} / \mathrm{L}$ for Fe, and from 2 to $200 \mu \mathrm{g} / \mathrm{L}$ for $\mathrm{Mn}$. These elements are mobilized by the surface runoff during the monsoon season and their common origin is to be found in the weathered bedrock.

In regards of the WHO drinking water guidelines, no major or trace elements exceed the recommended values, even if the concentrations for some major or trace elements of the Imja River are elevated.

\section{Stable Isotopes}

Three complete years (2014-2016) of meteorological data (P, T) are available at the Pangom station $(2885 \mathrm{~m}$, label D) (Chevallier et al., 2017), and a monthly sampling of rainfall for water isotope analysis was carried out between November 2014 and December 2016. The comparison of all the results is only qualitative owing to the small temporal record at the Pangom weather station.

The mean annual temperature measured at Pangom in 2015 was $6.7^{\circ} \mathrm{C}\left(7.6^{\circ} \mathrm{C}\right.$ in 2014 and $8.0^{\circ} \mathrm{C}$ in 2016) with lower temperatures in the dry season (minimum in December: $-1.1^{\circ} \mathrm{C}$ ) and higher temperatures during the monsoon season (Figure 6) (maximum in June: $12^{\circ} \mathrm{C}$ ). In the higher part of the Khumbu valley at the Pyramid Laboratory station, monthly temperatures follow the same pattern ranging between -12 and $4^{\circ} \mathrm{C}$ for the 2012-2014 interval (Balestrini et al., 2016).

\section{Precipitations}

Annual rainfall in Pangom was $3046 \mathrm{~mm}$ in 2015 (3683 mm in 2014 and $3947 \mathrm{~mm}$ in 2016). The South Asia monsoon (JJAS) accounts for more than $80 \%$ of the precipitation amount (Figure 6) (84.7-86.1\% from 2014 to 2016) with no specific rainier month in this season (JAS between 888 and $1075 \mathrm{~mm}$ ).

During the sampling interval (November 2014 to December 2016, with a gap in May 2016), a large isotopic variation is observed (Figure 6): 3.25 to $-15.26 \%$ V-SMOW for $\delta^{18} \mathrm{O}$ and 43.3 to $-109.5 \%$ V-SMOW for $\delta^{2} \mathrm{H}$. Figure 6 shows the isotopic composition of all precipitations giving a local water line following the equation:

$$
\delta^{2} \mathrm{H}=8.57 \delta^{18} \mathrm{O}+20.5 \quad\left(R^{2}=0.997 ; n=25\right)
$$

The slope is slightly higher than the slope of the global meteoric water line (GMWL, $\delta^{2} \mathrm{H}=8.13 \delta^{18} \mathrm{O}+10.13$ ) defined by Rozanski et al. (1993) and also shows an intercept $d=20.5$ higher, close to the meteoric line of the precipitation in the southern
Tibetan plateau (Yao et al., 2013):

$$
\delta^{2} \mathrm{H}=8.89 \delta^{18} \mathrm{O}+23.0 \quad\left(R^{2}=0.980 ; n=374\right) .
$$

At the Pyramid Laboratory station at the weekly scale between June 2012 and December 2013, Balestrini et al. (2016) found:

$$
\delta^{2} \mathrm{H}=8.17 \delta^{18} \mathrm{O}+16.6
$$

In Pangom, if one distinguishes between the seasons, the equations are:

$$
\begin{aligned}
& \text { ONDJFMAM (extra-monsoon) } \\
& \qquad \delta^{2} \mathrm{H}=8.46 \delta^{18} \mathrm{O}+20.6 \quad\left(\mathrm{R}^{2}=0.997 ; \mathrm{n}=17\right) \\
& \text { JJAS (monsoon), } \\
& \quad \delta^{2} \mathrm{H}=8.52 \delta^{18} \mathrm{O}+18.4 \quad\left(\mathrm{R}^{2}=0.999 ; \mathrm{n}=8\right) .
\end{aligned}
$$

The more enriched monthly values above $-1 \%$ in $\delta^{18} \mathrm{O}(n=5)$ do not show an evaporation mark; a high deuterium excess is observed (between 17.4 and $21.6 \%$ ) for low to medium rainfall amount (21 to $142 \mathrm{~mm}$ ). These values belong to the extramonsoon season and are linked to notable continental recycling mainly from non-fractional processes such as transpiration or soil evaporation. In the regional study by Jeelani and Deshpande (2017), stations in Nepal and Assam also showed a high d-excess $\left(>20 \%\right.$ ) associated with a high $\delta^{18} \mathrm{O}>-1 \%$ value, suggesting a dominant influence of transpiration, increasing the $\delta^{18} \mathrm{O}$ of vapor over the forest floor (Lai and Ehleringer, 2010).

The isotopic values recorded during the 2 years, including monsoon and extra-monsoon seasons, display different patterns, globally more depleted in the monsoon season $(2015,-10.05 \%$; $2016,-8.48 \%$, weighted mean for $\delta^{18} \mathrm{O}$ ) and more enriched in the extra-monsoon season $(2015,-4.48 \%$; $2016,-0.81 \%$, weighted mean for $\delta^{18} \mathrm{O}$ ). The much more enriched values in the extra-monsoon season in 2016 could be an effect on isotope composition and deuterium excess in the beginning of the monsoon season with a possibly late isotope re-equilibration of the air mass, perhaps due to higher mixing with the recycled continental vapor. Indeed, in June and July 2016, isotope values were more enriched than in June and July 2015, also with a greater d-excess. Then, it is only in August 2016, in the middle of the monsoon season, that isotope values and d-excess seem to be consistent with isotope values in the monsoon season, and this continues until the beginning of the extra-monsoon season (October 2016) with a dephasing of 2 months.

The relationship between isotope values and temperature (temperature effect) shows an inverse correlation with a low coefficient $(R=-0.336 ; n=25)$ as well as with rainfall (amount effect) with $R=-0.392$, which are not significant using a $\mathrm{t}$-distribution with $\mathrm{n}$-2 degrees of freedom at a significance level $a=0.05$; the critical values associated with $d f=23$ are \pm 0.396 (Bravais-Pearson table). The monsoon season corresponds to a more depleted rainfall (Dansgaard, 1964). In fact, the main effect on isotope variability in our site is the origin of air masses, as shown in previous regional studies cited in this article or in the local Khumbu Valley at the Pyramid Laboratory (Balestrini et al., 2016). 


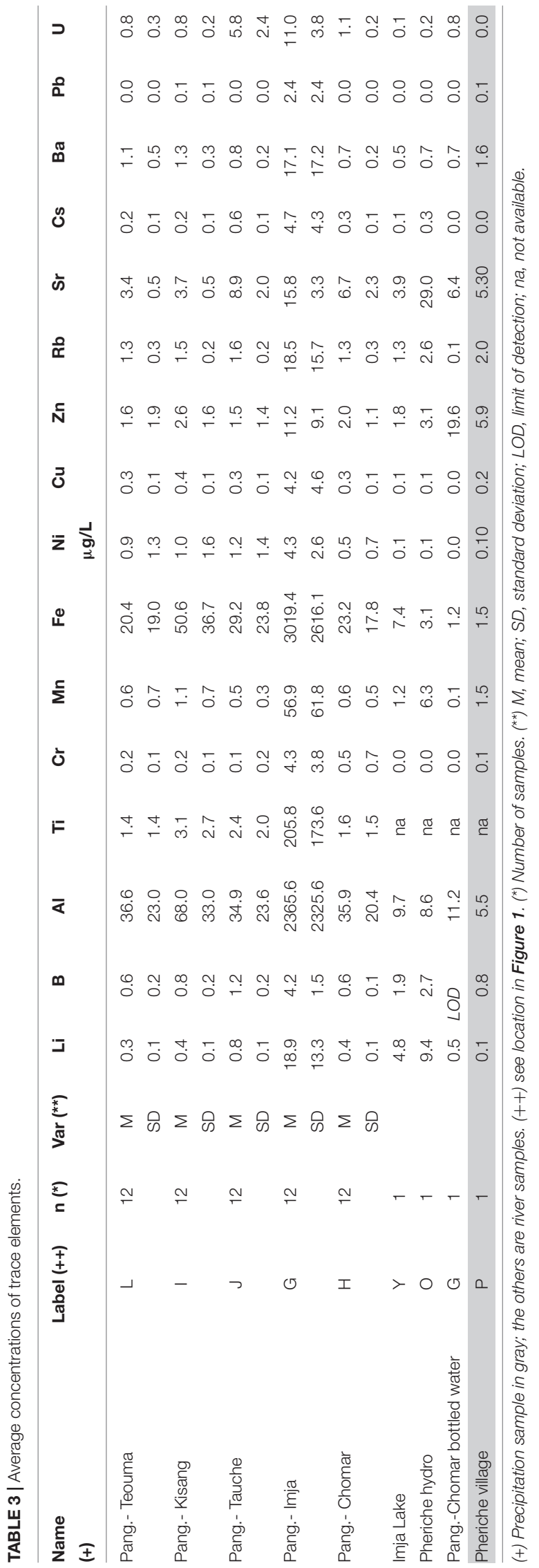

The year 2015, which is complete, gives a weighted annual value $\left[\Sigma\left(\mathrm{P}_{i} \delta_{i}\right) / \Sigma \mathrm{P}_{i}\right]$ of $-9.24 \% \mathrm{~V}$-SMOW for $\delta^{18} \mathrm{O}$ and $-60.1 \%$ V-SMOW for $\delta^{2} \mathrm{H}$ (2016: $95.9 \%$ of rainfall, $-8.20 \%$ and $-50.6 \%$ ), which is in good agreement with the altitude effect in the region, regarding the results obtained in Kathmandu (1320 m, -8.7\%0) and Nyalang (3811 m, -11.3\%o) (Wen et al., 2012; Balestrini et al., 2016); at the Pyramid Laboratory station $(5050 \mathrm{~m})$, the isotope content during the monsoon season in 2012 and 2013 does not show a large variation $\left(-17.74\right.$ to $-17.81 \%$ in $\left.\delta^{18} \mathrm{O}\right)$. The gradient is $-0.23 \% / 100 \mathrm{~m}$, in good agreement with the range of the isotope altitudinal gradient in Himalaya $(-0.15,-0.33 \% 0)$ (Wen et al., 2012).

The d-excess is a good indicator for evaluating the contribution of different water vapor sources (Clark and Fritz, 1997). In Himalaya, low d-excess values characterize moisture coming from the Indian Ocean and the Bay of Bengal, and high values continental moisture carried by the Western Disturbance (Jeelani and Deshpande, 2017). At Pangom in 2015 and 2016, d-excess values during the monsoon season were between 11.3 and $18.7 \%(n=8$, mean $=13.6 \%)$, while in the two extramonsoon seasons (2015 and 2016) d-excess values were between 14.3 and $23.9 \% 0(n=14$, mean $=19.1 \% 0)$.

At the Pyramid Laboratory, we have the same pattern for isotope content and d-excess during the monsoon (depleted values up to $-30 \%$ for $\delta^{18} \mathrm{O}$ and $\mathrm{d}$-excess $<15 \%$ ) and the extra-monsoon seasons (more enriched values and high d-excess until 26\%0). The difference observed with the local meteoric line (LML) in d-excess is due to the different repartition of measurements in the monsoon season $(n=38)$ and the extramonsoon season $(n=8)$.

We note in the total observed interval a good correlation between oxygen-18 and d-excess values $\left(R^{2}=0.62 ; n=25\right)$, which reaches $R^{2}=0.72$ if the more enriched point is removed (April 2016); this may indicate a slight alteration in isotope air mass signal by the evaporation process.

To conclude, in Pangom as in other Himalayan sites, the change in air circulation patterns, marine vapor from the Indian Ocean and the Bay of Bengal, on the one hand, and continental vapor from the Western Disturbances, on the other, modify the isotope composition and d-excess of precipitation.

\section{Rivers}

For the river isotope sampling, in the general spatial pattern, depleted values are observed in the headwaters of the streams and enriched values at lower elevations of the catchments. The water isotope variability of stream water shows a lower variability with respect to local precipitation at Pangom, in spite of altitudinal sampling (1981-4935 m) and six campaigns between November 2014 and May 2017 (local sampling between one and six campaigns) that ranged from -10.10 to $-18.39 \%$ for $\delta^{18} \mathrm{O}$ and from -64.5 to $-135.8 \%$ for $\delta^{2} \mathrm{H}$ (Figure 7 and Table 4). The sampling was carried out at the beginning of the extra-monsoon season, with possibly the influence of the end of the monsoon season, and at the end of the extra-monsoon season. However, the variability registered is mainly very low, 
lower than $0.6 \%$ for $\delta^{18}$ O for $89 \%$ of local stations. Two stations with at least five samplings (D - Pangom and J - Tauche) show a large difference; both stations in March 2015 have a high depleted value $\left(-16.65\right.$ and $-16.53 \%$ in $\delta^{18} \mathrm{O}$, respectively); not considering this result, Pangom has a mean value of $-10.47 \%$ with a range interval of $0.45(n=4)$ and Tauche has a mean value of $-15.31 \%$ with a range interval of $1.22(n=5)$. Both sampling points are located in non-glaciated catchment for Pangom and small glaciated catchment (less than $1 \%$ of the basin area) for Tauche. The river in this extra-monsoon season with few precipitations (at Pangom in 2015, precipitation amounts are $19 \mathrm{~mm}$ in January, $19 \mathrm{~mm}$ in February and $66 \mathrm{~mm}$ in March) is supplied mainly by superficial aquifer whose main characteristic is an isotopic composition relatively constant over the year at a local altitudinal point (Jeelani et al., 2018). The main hypothesis to explain this important change is the presence of snow cover at higher altitude with more depleted isotopic content during this season, which was melting and supplied by direct runoff from the river.

Although there were no measurements during the monsoon season in this study, the works of Balestrini et al. (2014) in the high part of the Khumbu Valley $(>4200 \mathrm{~m}$ ) have shown a higher variability $(2 \%)$ close to glacier and morainic lake inflow and low variability $\left(0.39 \%\right.$ in $\left.\delta^{18} \mathrm{O}\right)$ at Pheriche (label P in Figure 1) during monthly sampling between July and October 2008. The authors suggest that the area extension of the hydrological basin buffers the isotopic signal. Another fact is the difficulty to link directly the isotope content of monthly precipitation and isotopic content of river water at the same time.

The isotopic composition of the stream water in the whole study interval is close to the local precipitation regression line (Figure 7) following the equation:

$$
\delta^{2} \mathrm{H}=8.23 \delta^{18} \mathrm{O}+15.0 \quad\left(\mathrm{R}^{2}=0.987 ; \mathrm{n}=58\right)
$$

For each season the slope and the d-excess value can differ greatly, but the number of samples is small (except for May 2017, which is close to the global river equation) and these variations are not representative of a particular process:
November 2014

November 2015

May 2016

May 2017
March 2015

November 2016

$$
\begin{aligned}
& \delta^{2} H=8.11 \delta^{18} \mathrm{O}+4.1 \\
& \delta^{2} \mathrm{H}=7.56 \delta^{18} \mathrm{O}+22.2 \\
& \delta^{2} \mathrm{H}=6.71 \delta^{18} \mathrm{O}+9.3 \\
& \delta^{2} \mathrm{H}=8.24 \delta^{18} \mathrm{O}+16.3 \\
& \delta^{2} \mathrm{H}=8.08 \delta^{18} \mathrm{O}+13.3 \\
& \delta^{2} \mathrm{H}=8.47 \delta^{18} \mathrm{O}+19.1
\end{aligned}
$$

$\left(R^{2}=0.972 ; n=5\right)$

$\left(R^{2}=0.999 ; n=9\right)$

$\left(R^{2}=0.934 ; n=11\right)$

$\left(R^{2}=0.994 ; n=10\right)$

$\left(R^{2}=0.992 ; n=9\right)$

$\left(R^{2}=0.997 ; n=17\right)$ between 11 and 14\%o. For d-excess values higher than 14\%o, there is possibly a partial contribution of rainfall or melted snow during the extra-monsoon season where d-excess values of monthly precipitation can reach $24 \%$ during the 20142016 interval.

Contrary to the results of another study in southern Himalaya by Wen et al. (2012), who found a very good correlation between the isotope content in the Boqu River and altitude $(n=39$, $R^{2}=0.90$, September 2011) between 1845 and $5060 \mathrm{~m}$, the relationship between the altitude of the sampling sites and isotope content is not well correlated $\left(R^{2}=0.399 ; n=18\right)$ very likely due to the heterogeneity of the catchments and their glacier cover varying between 0 and $70 \%$. The river in catchments with glacier cover at all altitudes is mainly controlled by the ice melting and by higher depleted value with respect to no glacier catchments. This is the case of the Phakding samples, located at a low altitude $(2620 \mathrm{~m})$, which show an isotope content in $\delta^{18} \mathrm{O}$ of $-15.89 \%$, with a $20.9 \%$ glacier cover (Everest catchment). By comparison, the weighted mean annual rainfall in Pangom $(2890 \mathrm{~m})$ yields $-9.24 \%$, in better accordance with the isotope values collected in the Pangom River (watershed without glacier) and reflecting the isotope composition of rainfall in the whole study area $(-11.71 \% 0)$.

By contrast, rivers in catchments without any or with small glacier cover (Kharikola, Pangom, Tauche, Chomar, Teouma), spring (Lobuche spring), or surface flow not connected to glacier melt such as wet saturated pastures (kharka in Nepali; e.g., Phulung Kharka) show (Figure 8) a better correlation with altitude $\left(R^{2}=0.809 ; n=8\right)$. Focusing only on the river sampling points that depending on glacier melt, the correlation with altitude is significantly improved $\left(R^{2}=0.525 ; n=10\right)$. Indirectly, the lower the altitude, the more the glacier component in the river decreases and the more the aquifer component increases.

The isotopic altitude gradient for river sampling in no or in a lightly glaciated catchments shows for $\delta^{18} \mathrm{O}$ a value of $-0.20 \% / 100 \mathrm{~m}$; this is in the range $(-0.11 /-0.36 \% / 100 \mathrm{~m})$ of other studies referenced by Wen et al. (2012) and Ren et al. (2017) in Himalaya and is close to results found by Florea et al. (2017), in the same zone, i.e., $-0.28 \%$ o $/ 100 \mathrm{~m}$. By comparison with the study of Florea et al. (2017), in the Dudh Koshi River with a sampling set located between Gorak Shek $(5180 \mathrm{~m})$, upstream of Lobuche, and downstream of Phakding $(2550 \mathrm{~m})$ in May 2011, values in $\delta^{18} \mathrm{O}$ are between -17.9 and $-9.7 \%$. The relationship between $\delta^{18} \mathrm{O}$ and $\delta^{2} \mathrm{H}$ demonstrates a lower slope and d-excess value than our global study, with the equation:

$$
\delta^{2} \mathrm{H}=7.8 \delta^{18} \mathrm{O}+4.0 \quad\left(R^{2}=0.94 ; n=32\right) .
$$

The mean d-excess value at each sampling point is between 5.6 and $14.4 \%$. For the whole dataset, d-excess values vary between 3.1 and $15.6 \%$ with $19 \%$ of samples lower than $10 \%$, which are altered by an evaporation process. The samples with d-excess between 10 and $14 \%$ do not show a special trend, likely linked to glacier melt and aquifer discharge where the main accumulation and recharge are during monsoon season when the d-excess value of the monthly precipitation is
Individually, tributary streams and direct sampling in the Dudh Koshi River show a d-excess ranging between 4.4 and $12.7 \%$ (72\% of samples lower than $10 \%$ ), which is globally lower than the d-excess measured in this study. The slope is lower than 8 , but overall the low d-excess values imply that an evaporation process during the study interval (Florea et al., 2017) may be due to the sampling time (end of extra-monsoon 


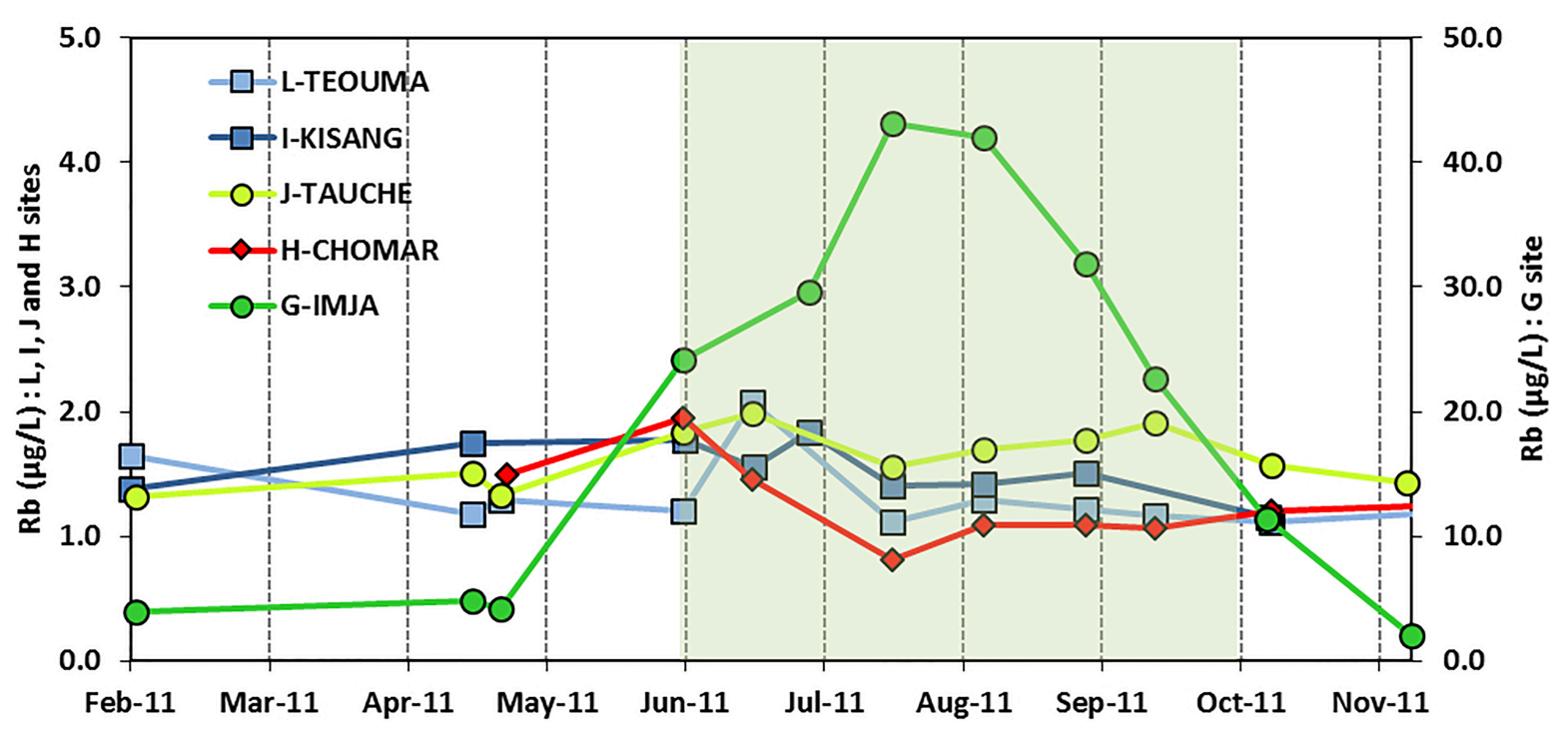

FIGURE 5 | Temporal variation of Rb concentration. The monsoon season is highlighted in green.

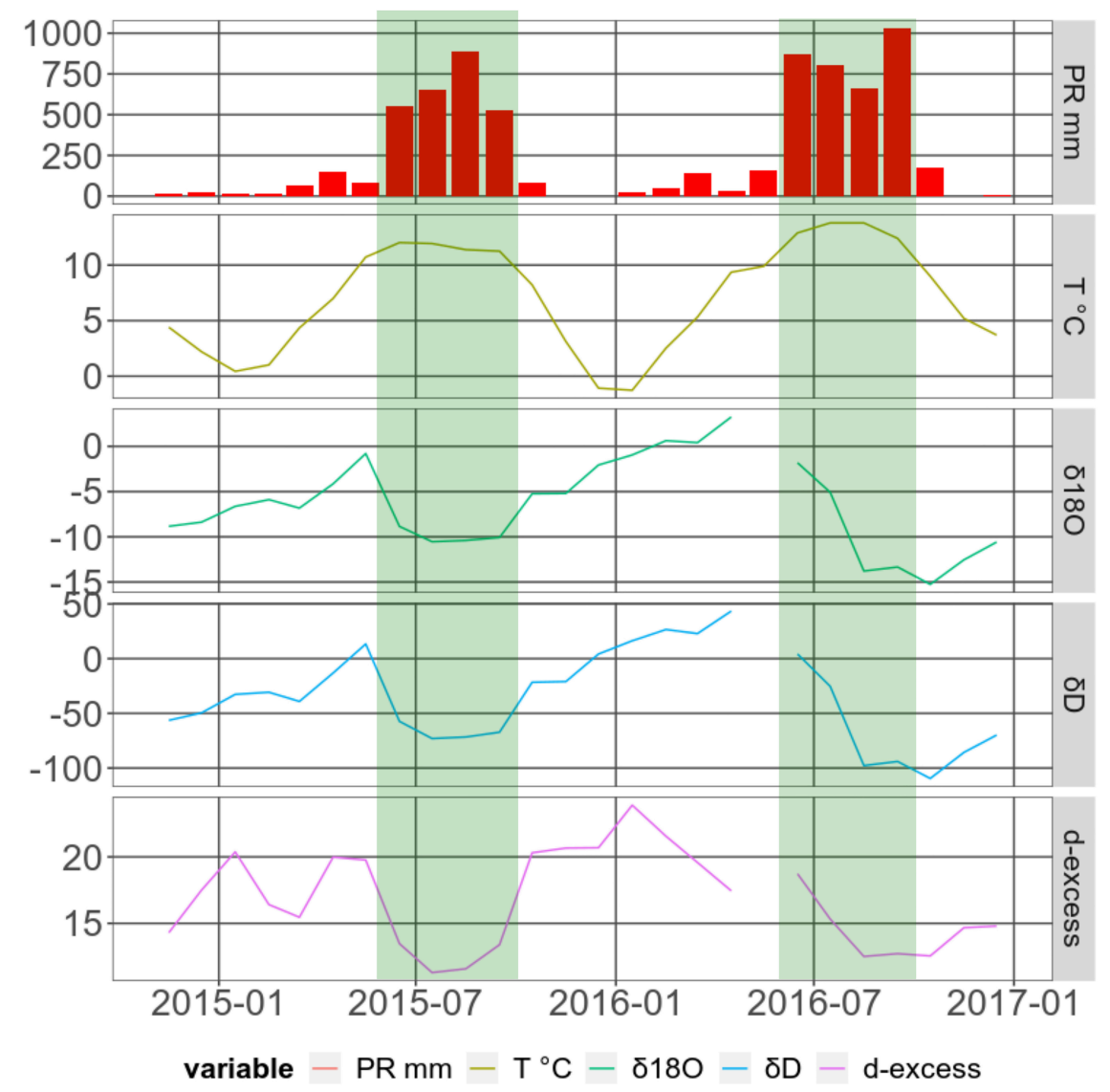

FIGURE 6 | Monthly precipitation data in Pangom (E): precipitation (PR), air temperature (T), and stable isotopes $\left(\delta^{18} \mathrm{O}, \delta \mathrm{D}\right.$, d-excess, \%o VSMOW). The monsoon seasons (JJAS) are highlighted in green. 


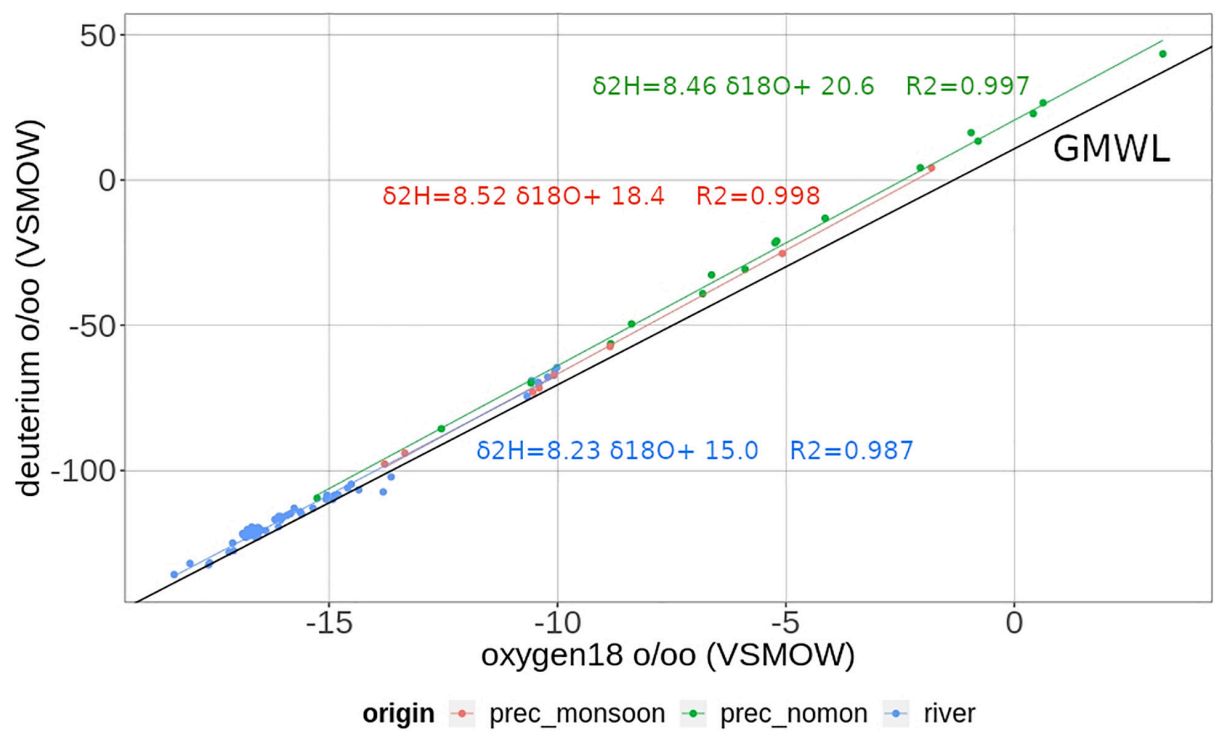

FIGURE $7 \mid \delta^{18} \mathrm{O}$ versus $\delta^{2} \mathrm{H}$ for precipitation samples in Pangom (monsoon and extra-monsoon seasons in red and green, respectively) and for river samples in blue, compared with the Global Meteoric Water Line (GMWL).

season), with warmer conditions than during the sampling times of this study.

\section{DISCUSSION}

\section{Water Origins}

Not surprisingly, the isotope properties of the precipitation highlight the double climatic influence from the arrival of the westerlies in winter and from the Asian monsoon in summer.

The isotope response to ground ice melt has been investigated since the mid-1970s (Stuiver et al., 1976; Fujino and Kato, 1978) who relies on isotope fractionation that occurs during phase changes (i.e., freezing, condensation, adsorption) and the resulting difference in the slope of the regression of $\delta \mathrm{D}$ on $\delta^{18} \mathrm{O}$ with a slope between 3 and 7 (Jouzel and Souchez, 1982; Lacelle, 2011). Ala-aho et al. (2018) show in western Siberia the possible discrimination of water origin between precipitation, river, lakes and thawing permafrost. The slope of the regression of $\delta \mathrm{D}$ on $\delta^{18} \mathrm{O}$ was lower than the precipitation (7.6) with soils/permafrost $(4.64)<$ lakes $(5.54)<$ rivers $(6.08)$ and a strong variability of median isotope content in precipitation $(-15.6 \%$ in $\left.\delta^{18} \mathrm{O}\right)$, rivers $(-15.3 \%)$, soils/permafrost $(-13.0 \%)$ and lakes $(-11.1 \% 0)>$ rivers $(-15.1 \%)$. In our study case the river points do not show an obvious influence of thawing permafrost during the sampling period which correspond before or after monsoon when temperatures are lower, may-be during monsoon period of higher temperature, an important thawing permafrost could be detected in some rivers.

Locally, the results of the current study confirm that few chemical patterns can be used to distinguish the waterflow origins during the different seasons. $\mathrm{Rb}$, as $\mathrm{Li}, \mathrm{Cu}, \mathrm{Sr}, \mathrm{Ba}$, and $\mathrm{SiO}_{2}$, originating from the minerals of the bedrock, characterizes substantially the water originating from glacier melt, as shown in Figure 5, especially during the monsoon season. Nevertheless, the isotopic results appear to be less useful for that task, even if differences are observed: the isotopic climate signal in the water courses is very likely mixed with the signal emitted by the storage in groundwater temporary reservoirs, which limits a clear interpretation. Factually, it depends on the sampling location and of the ratio of glacierized area. In the high altitudes $(>4000 \mathrm{~m})$ the river reflects the isotope content mainly of the ice and snow melt because the climatic conditions do not allow an important weathering of the rocks and a strong development of an aquifer structure; the consequence is a reduced groundwater capacity, and a fast groundwater circulation reflecting isotope content of ice and snow. At lower altitude, the weathering is higher and the aquifer can develop itself with a higher storage capacity involving local recharge by rainfall; the isotope content is enriched with respect to ice and snow melt (altitude effect): the lower the altitude, the richer is the isotope content of total flow. It is a consequence of the higher base flow in the dry season and of the higher contribution of the surface runoff in the monsoon season, this last being enriched in isotope with respect to ice and snow melt more depleted.

However, the meltwater marking (glacier as snow cover melt) by the isotopes can be more visible than by the chemical signature in downstream sampling sites, because it is less dissolved, with the inconvenience of a smoothed seasonal effect. The result at the Phakding (20.9\% glacier covered) and Pangom (no glacier) stations, detailed in the previous section, is, therefore, significant.

The $\mathrm{pH}$ remains in a relatively narrow range in the different sampling points and does not seem useful for characterizing the water paths or the seasons, while electrical conductivity shows slightly higher values for flows originating from glaciers and lower values in the monsoon runoffs of streams not fed by glacier melt (Figure 2). 
TABLE 4 | Main characteristics of the stable isotope river samples.

\begin{tabular}{|c|c|c|c|c|c|c|c|c|c|c|c|c|c|}
\hline \multirow[t]{2}{*}{ Name } & \multirow[t]{2}{*}{ Label (+) } & \multirow[t]{2}{*}{ Altitude (m) } & \multicolumn{6}{|c|}{ Sampling seasons $(*)$} & \multicolumn{5}{|c|}{ Isotope data } \\
\hline & & & N14 & MH15 & N15 & MY16 & N16 & MY17 & Mean ${ }^{18} \mathrm{O}$ & Mean D & Maximum difference ${ }^{18} \mathrm{O}$ & maximum difference $D$ & Mean d-excess \\
\hline Kharikhola & $A$ & 1981 & & & & $x$ & $x$ & $x$ & $-10,16$ & $-66,9$ & 0,40 & 5,4 & 14,4 \\
\hline Phakding & $B$ & 2620 & & $x$ & $x$ & $x$ & $x$ & $x$ & -15.89 & -114.87 & 0.47 & 2.9 & 12.2 \\
\hline Jorsalle & $\mathrm{C}$ & 2850 & & $x$ & $\times 2$ & & $x$ & $x$ & -16.05 & -116.3 & 0.34 & 2.1 & 12.1 \\
\hline Pangom river & D & 2880 & $x$ & $x$ & & $x$ & & $x$ & -11.71 & -80.5 & 5.98 & 53.6 & 13.2 \\
\hline Phunki Tenga & $\mathrm{F}$ & 3200 & & $x$ & $x$ & $x$ & $x$ & $\times 2$ & -16.54 & -120.5 & 0.20 & 0.1 & 11.8 \\
\hline Pangboche-Imja & G & 3917 & & & $x$ & $x$ & $x$ & $x$ & -16.67 & -120.7 & 0.22 & 2.5 & 12.6 \\
\hline Pangboche-Tauche & J & 4005 & $x$ & $x$ & $x$ & $x$ & $x$ & $x$ & -15.51 & -113.7 & 1.65 & 10.9 & 10.3 \\
\hline Shomare & K & 4021 & $x$ & & $x$ & & & & -14.08 & -107.2 & 0.53 & 0.7 & 5.6 \\
\hline Pangboche-Teouma & $\mathrm{L}$ & 4148 & & & $x$ & $x$ & $x$ & & -14.6 & -107.8 & 1.70 & 10.8 & 8.9 \\
\hline Pheriche hydro & $\mathrm{O}$ & 4216 & & & $x$ & $x$ & $x$ & $x$ & -16.7 & -121.7 & 0.39 & 2.29 & 11.9 \\
\hline Pheriche village & $P$ & 4260 & $x$ & & & & & & -16.55 & -122.8 & & & 9.6 \\
\hline Dingboche village & $Q$ & 4370 & $x$ & & $x$ & $x$ & & $x$ & -16.83 & -121.7 & 0.57 & 5.2 & 12.9 \\
\hline Dingboche hydro & $\mathrm{R}$ & 4372 & $\times 2$ & & & & & & -17.63 & -132.2 & 0.03 & 0.7 & 8.8 \\
\hline Tauche Kharka & S & 4405 & & & & $x$ & & & -14.51 & -104.7 & & & 11.4 \\
\hline Phulung Kharka & T & 4504 & $\times 2$ & & & & & & -17.13 & -127.9 & 0.10 & 0.47 & 9.2 \\
\hline Tukla & $U$ & 4700 & $x$ & & $x$ & & & & -18.21 & -133.93 & 0.35 & 3.84 & 11.8 \\
\hline Lobuche river & w & 4840 & $\times 2$ & & & & & & -16.71 & -123.03 & 0.21 & 0.1 & 10.7 \\
\hline Lobuche spring & $x$ & 4935 & & & $x$ & & & & -15.06 & -109.9 & & & 10.5 \\
\hline
\end{tabular}

(+) See location in Figure 1. (*) Axx: A = M (monsoon) or (extra-monsoon); xx is the year (e.g., $14=2014)$. N14, November 2014; MH15, March 2015; N15, November 2015; My16, May 2016, N16, November 2016; My17, May 2017. 


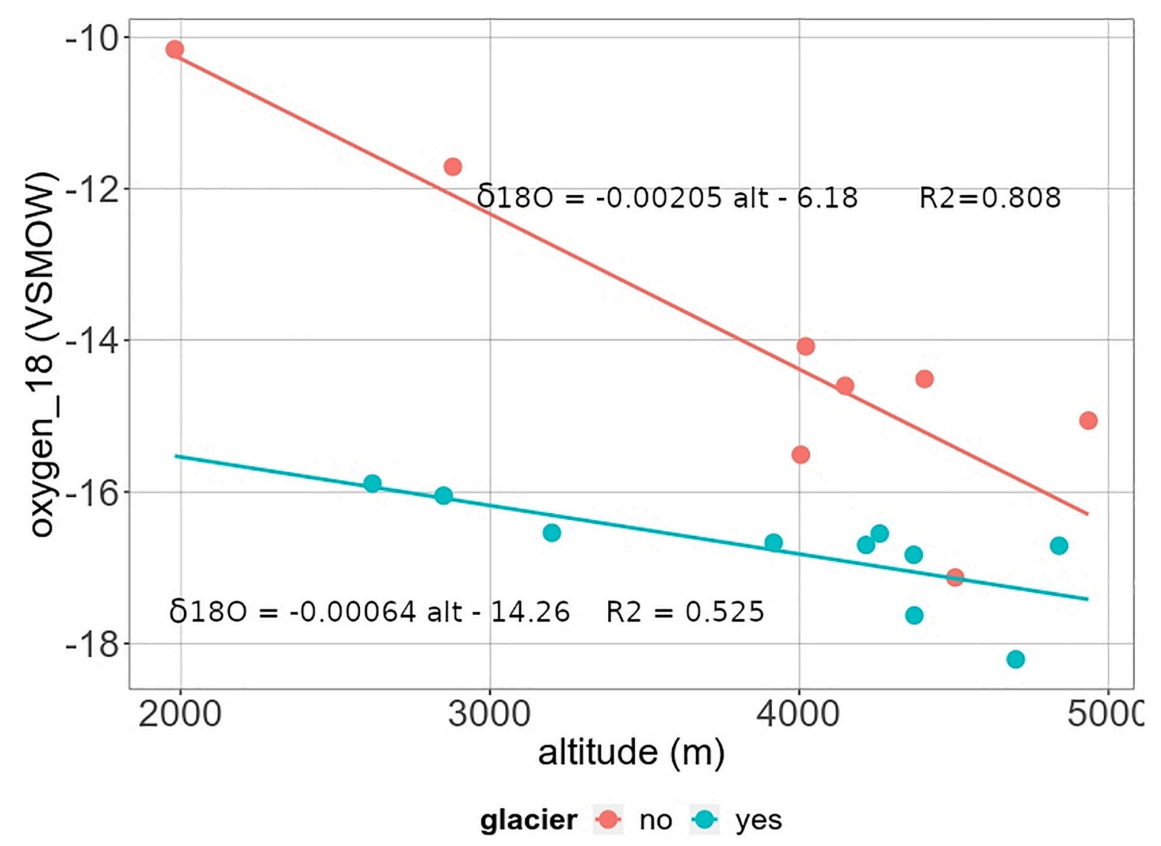

FIGURE 8 | Isotope altitude gradient from sampling in no glacier watershed (isotope value determined by local rainfall and aquifer isotope value), and sampling in partial glacier watershed (isotope value determined by mixing between melt from high altitude and local rainfall and aquifer isotope value).

TABLE 5 | Additional observations of electrical conductivity, performed on June 19, 21, and 22, 2012.

\begin{tabular}{lcc}
\hline Name & Label $(+)$ & Electrical conductivity $(\boldsymbol{\mu} \mathbf{S} / \mathbf{c m})$ \\
\hline Pangboche-Imja & G & 53.0 \\
Khumbu confluence & $\mathrm{N}$ & 67.6 \\
Pheriche hydro & $\mathrm{O}$ & 62,6 \\
Imja confluence & $\mathrm{M}$ & 35.4 \\
Dingboche hydro & $\mathrm{R}$ & 32.9 \\
Chukung & $\mathrm{V}$ & 41.5 \\
Imja Lake $\left(^{*}\right)$ & $\mathrm{Y}$ & 29.7 \\
& & 30.7 \\
& & 29.6
\end{tabular}

(+) See location in Figure 1. $\left(^{*}\right)$ Three different sampling points in the outlet narrows.

In addition to the previous considerations, complementary observations on electrical conductivity were made in the main rivers of this area and in the Imja Lake during a 3day interval in the second half of June 2012, in the early monsoon season. They are summarized in Table 5, which shows that the flows arising from the Imja Lake are approximately twofold less mineralized than those of the Khumbu upper valley. Both basins have similar areas and ratios of glaciated surfaces. Because the flows are from the same geological and glaciological origin, the conductivity difference observed can only be explained by the presence of the lake. The higher value observed in the lateral Imja River, which does not flow from the lake, confirms this hypothesis. This phenomenon could be attributed to the sedimentation only within the lake of the solid load generated by the glacier abrasion, due to

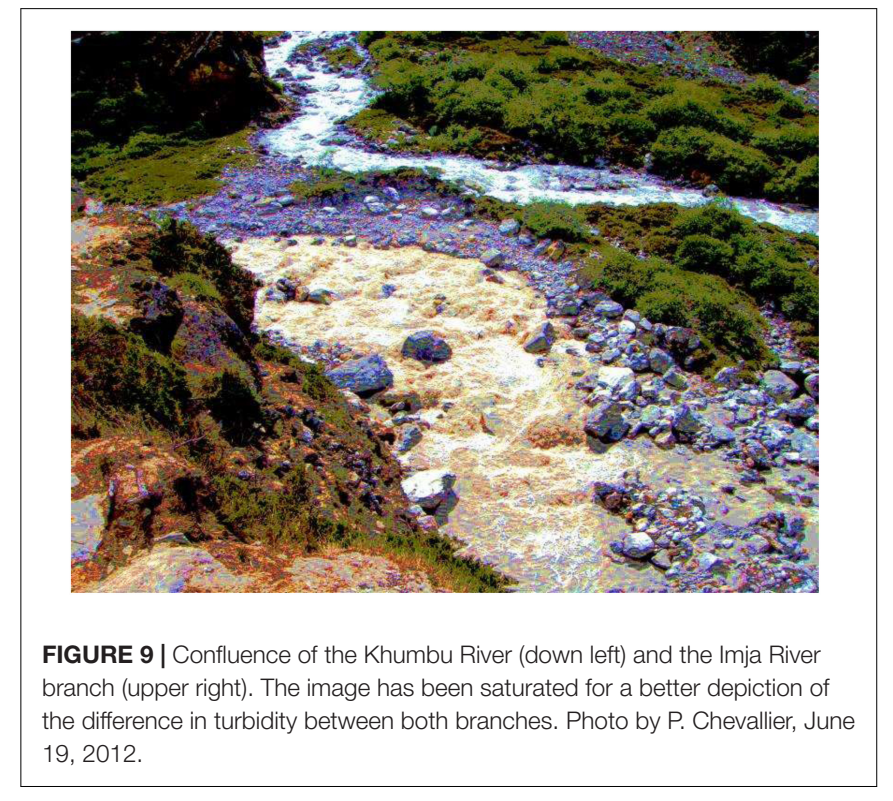

quieter hydraulic conditions. This hypothesis is reinforced by the visual observations at the confluence between the Imja and the Khumbu rivers, which showed that the turbulence of the runoff was higher in the Khumbu branch than in the Imja branch (Figure 9).

\section{Water Uses}

Before commenting, it must be stressed that in the framework of this study no analysis was performed regarding the 
bacterial and organic quality of the water used by the inhabitants and by the visitors. The reason is that, at the time of the study, the only laboratory for analyzing samples, poorly equipped and without dedicated manpower, was located in the Khumjung Hospital, close to the village of Namche Bazar, several hours' walking distance from the sampling points. This is unfortunate, because the sources of bacterial and organic pollution are numerous, especially highaltitude pastures, perfunctory toilet installations, uncontrolled waste disposal, etc. (Manfredi et al., 2010). These sources of pollution are increasing with the rapid development of tourist activities. Furthermore, inhabitants in Pangboche expressed more concerns about the future of the water quality than about water quantity since no proper sewage system exists and they are witnessing a dissemination of plastic waste in streams.

The quality of the natural water can be chemically considered good with a very low mineralization degree. It appears that the reticence to consider the water of the large valley river is mainly justified by the danger in accessing and harvesting it and also by its white color, due to the fine particles mentioned in the previous section. This particular property gave its name to the Dudh Koshi River, which means Milk River in Nepali. Nevertheless, these statements cannot conclude on the drinkability of the river water, since, as written above, organic and microbiological analysis have not been done in the current study framework.

The sampling points L (Pangboche-Teouma) and I (Pangboche-Kisang) were chosen for their location, upstream and downstream of the village, respectively, in order to examine an eventual degradation due to the human activities. No notable differences can be observed in terms of the major ions (Table 2). Nevertheless, in Figure 4, the trace elements collected throughout the year in Teouma (upstream) appear grouped, when a dispersion is noted for those collected downstream in Kisang. This dispersion is very likely due to the limited pollution of the water used in the village. Shortly after Kisang, the slope torrent is intercepted by the large Dudh Koshi River, where the low chemical pollution is dissolved.

Finally, the issue of bottled water consumption by tourists is of some importance to the local economy, because it is a non-negligible income for the communities (Puschiasis, 2015; Jacquemet, 2018). Several small companies have been established in the region to exploit this niche. One of them collected water at the Pangboche-Chomar point (labeled H in Figure 1) and, after a basic filtration process, bottled it. The bottled water was also analyzed with the same procedure as the other samples, except that it was transported to France after several months in the original PET bottle and not in a standard analysis recipient (see section "Conductivity, Major, and Trace Elements"). As shown in Figure 4, no difference is observed between the bottle and the other samples from the Chomar site. In Table 2, a few differences are notable, especially regarding $\mathrm{pH}, \mathrm{Cl}^{-}, \mathrm{NO}_{3}^{-}$, and $\mathrm{Na}^{+}$. They can be explained by the very long storage in a bad-quality recipient, but this is the reality for most of the water bottles available in the study zone.
Nevertheless, in terms of chemical quality, the bottled water and the river water are similar. It seems that for some reason the water company did not pursue the exploitation of the Chomar site, which no longer functioned after 2013. However, water bottles from other places, particularly those collected in the surroundings of Namche Bazar, were sold in the Pangboche shops and lodges.

\section{CONCLUSION}

Between many studies, the recent IPCC special report on the cryosphere future (Pörtner et al., 2019) confirms the loss of cryospheric mass and the rapid permafrost thaw. It is also verified in the Central Himalaya, which presents threats on physical entities (water resources, flood, landslide, avalanche) and on ecosystems (forest, tundra). The Khumbu inhabitants are strongly preoccupied by this situation, which directly impacts their livelihood. In addition, they face difficulties in terms of inequalities in the social water management system, failing to regulate proper access of water in villages (Puschiasis, 2015; Faulon and Sacareau, 2020). More than climatic variations, changes in water use over the past decades are due to a growing need for tourism and for domestic purposes. Regarding the future of accessible water resources, this does not seem to be threatened in terms of quantity, even if seasonal pressures should lead to a better water management, especially during the high season of tourism activities (Aubriot et al., 2019). However, water quality could evolve in a worrisome direction.

Apart from the bacteriological and organic issue, which is not considered here, the points addressed could change as follows:

- The isotopic signature of precipitation and rivers is a good indicator of climate change and flow paths. It should be periodically analyzed. On the one hand, it could follow changes observed in the seasonal precipitation patterns in the study region (Shea et al., 2015). On the other hand, it facilitates the recognition of the transitory storage of surface water (glacier, snow cover, or underground reservoirs).

- In this study the chemical properties of the water used for domestic activities do not seem to be hazardous to human and animal health at present. However, with changes in precipitation and river regimes, in land use and land cover due to economic income, in cropping strategies, in the very low level of waste and toilet water management, the current fragile balance could be seriously jeopardized. The project of road construction in the valley, for instance, validated until Surkhe, close to Lukla ("The Rising Nepal: Everest Region Closer with Bridge over Sunkoshi”. January 16, 2020. http://therisingnepal.org.np/news/1084. Accessed on August 10, 2020), will lead to the importation of chemical products and molecules that have been thus far unknown.

\section{DATA AVAILABILITY STATEMENT}

The raw data supporting the conclusions of this article will be made available by the authors, without undue reservation. 


\section{ETHICS STATEMENT}

Ethical review and approval was not required for the study on human participants in accordance with the local legislation and institutional requirements. Written informed consent for participation was not required for this study in accordance with the national legislation and the institutional requirements.

\section{AUTHOR CONTRIBUTIONS}

PC coordinated the whole study, including the field collection, wrote the introduction, discussion, and conclusion sections, and assembled the different parts of the manuscript. J-LS contributed to the geochemistry analysis of the major ions and trace elements and J-DT of the stable isotopes. OP lived in Pangboche during the whole year in 2011 at an elevation of $4000 \mathrm{~m}$, collecting the water samples and she wrote the parts regarding water use by the local inhabitants. All authors contributed to the article and approved the submitted version.

\section{FUNDING}

The global research action, the sample analysis, and the Ph.D. grant, followed by a post-doctoral grant, of OP were supported by Agence Nationale de la Recherche - France (references: ANR-09CEP-005-04/PAPRIKA and ANR-13-SENV-005-03/PRESHINE).

\section{REFERENCES}

Ala-aho, P., Soulsby, C., Pokrovsky, O. S., Kirpotin, S. N., Karlsson, J., Serikova, S., et al. (2018). Using stable isotopes to assess surface water source dynamics and hydrological connectivity in a high-latitude wetland and permafrost influenced landscape. J. Hydrol. 556, 279-293. doi: 10.1016/j.jhydrol.2017. 11.024

Andermann, C., Longuevergne, L., Bonnet, S., Crave, A., Davy, P., and Gloaguen, R. (2012). Impact of transient groundwater storage on the discharge of himalayan rivers. Nat. Geosci. 5, 127-132. doi: 10.1038/ngeo1356

André-Lamat, V. (2017). De l'eau Source à l'eau Ressource: Production d'un Capital Environnemental Ou d'un Commun. L'exemple de l'eau Domestique Au Pharak (Népal). Développement Durable et Territoires. Available online at: https:// halshs.archives-ouvertes.fr/halshs-01959313 (accessed December 18, 2018).

Aubriot, O., Faulon, M., Sacareau, I., Puschiasis, O., Jacquemet, E., Smadja, J., et al. (2019). Reconfiguration of the water-energy-food nexus in the everest tourist region of Solukhumbu, Nepal. Mountain Res. Dev. 39, R47-R59. doi: 10.1659/MRD-JOURNAL-D-17-00080.1

Balestrini, R., Delconte, C. A., Sacchi, E., Wilson, A. N., Williams, M. W., Cristofanelli, P., et al. (2016). Wet deposition at the base of Mt Everest: seasonal evolution of the chemistry and isotopic composition. Atmos. Environ. 146, 100-112. doi: 10.1016/j.atmosenv.2016.08.056

Balestrini, R., Polesello, S., and Sacchi, E. (2014). Chemistry and isotopic composition of precipitation and surface waters in Khumbu Valley (Nepal Himalaya): N dynamics of high elevation basins. Sci. Total Environ. 485-486, 681-692. doi: 10.1016/j.scitotenv.2014.03.096

Bonasoni, P., Laj, P., Marinoni, A., Sprenger, M., Angelini, F., Arduini, J., et al. (2010). Atmospheric brown clouds in the himalayas: first two years of continuous observations at the Nepal climate observatory-pyramid (5079 m). Atmos. Chem. Phys. 10, 7515-7531. doi: 10.5194/acp-10-7515-2010

Bookhagen, B., and Burbank, D. W. (2010). Toward a complete Himalayan hydrological budget: spatiotemporal distribution of snowmelt and rainfall and
Some monitoring equipment was acquired through the Glacioclim SNO (French National Observation Service).

\section{ACKNOWLEDGMENTS}

The analyses of major ions and trace elements were done by Sandra Van Exter and J-LS, and the analysis of stable isotopes by Nicolas Patris at the Laboratoire HydroSciences Montpellier (CNRS, IRD, University of Montpellier). Dawa Nuru Sherpa translated the dialogs with Pangboche's inhabitants and facilitated the measurements. Ang Jangmu Sherpa collected and stored the precipitation samples in Pangom. Yves Arnaud, Olivia Aubriot, Anneke De Rouw, François Delclaux, Judith Eeckman, Michel Esteves, Frédéric Hernandez, Devesh Koirala, Luc Neppel, Rémi Muller, Marie Savéan, Joëlle Smadja, and Patrick Wagnon participated in the field operations, as well as extraordinary, indispensable and friendly local porters. Yves Arnaud and Isabelle Sacareau were, respectively, the coordinators of the Paprika and Preshine projects, which benefited from a partnership with the following institutions: Nepalese Academy of Science and Technology (Kathmandu, Nepal), EvK2-CNR Association (Bergamo, Italy), International Center of Integrated Mountain Development (Kathmandu, Nepal), Tribhuvan University (Kathmandu, Nepal), and Department of Hydrology and Meteorology (Kathmandu, Nepal). Finally, the authors thank the two reviewers who allow to substantially improve the definitive version of the manuscript.

their impact on river discharge. J. Geophys. Res. Earth Surf. 115:F03019. doi: 10.1029/2009jf001426

Bortolami, G. (1998). "Geology of the Khumbu region, Mt Everest, Nepal," in Limnology of High Altitude Lakes in the Mt Everest Region, Nepal. Memorie Dell' Istituto Italiano Di Idrobiologia, Vol. 57, eds A. Lami and G. Giussani (Verbania: Instito per lo studio degli ecosistemi), 41-49.

Chevallier, P., Delclaux, F., Wagnon, P., Neppel, L., Arnaud, Y., Esteves, M., et al. (2017). Paprika - Preshine Hydrology Data Sets in the Everest Region (Nepal). 2010-18. Data base. 2017. Montpellier, France: Laboratoire HydroSciences. doi: 10.23708/000521

Clark, I., and Fritz, P. (1997). Environmental Isotopes in Hydrogeology. Boca Raton, FL: Lewis Publisher.

Crespo, S., Aranibar, J., Gomez, L., Schwikowski, M., Bruetsch, S., Cara, L., et al. (2017). Ionic and stable isotope chemistry as indicators of water sources to the Upper Mendoza River basin, Central Andes of Argentina. Hydrol. Sci. J. 62, 588-605. doi: 10.1080/02626667.2016.125 2840

Dansgaard, W. (1964). Stable isotopes in precipitation. Tellus 16, 436-468. doi: 10.1111/j.2153-3490.1964.tb00181.x

Dongol, B. S., Merz, J., Schaffner, M., Nakarmi, G., Shah, P. B., Shrestha, S. K., et al. (2005). Shallow groundwater in a middle mountain catchment of Nepal: quantity and quality issues. Environ. Geol. 49, 219-229. doi: 10.1007/s00254005-0064-5

Eeckman, J., Chevallier, P., Boone, A., Neppel, L., De Rouw, A., Delclaux, F., et al. (2017). Providing a non-deterministic representation of spatial variability of precipitation in the everest region. Hydrol. Earth Syst. Sci. 21, 4879-4893. doi: 10.5194/hess-21-4879-2017

Eeckman, J., Nepal, S., Chevallier, P., Camensuli, G., Delclaux, F., Boone, A., et al. (2019). Comparing the ISBA and J2000 approaches for surface flows modelling at the local scale in the everest region. J. Hydrol. 569, 705-719. doi: 10.1016/j.jhydrol.2018.12.022 
Faulon, M., and Sacareau, I. (2020). Tourisme gestion sociale de l'eau et changement climatique dans un territoire de haute altitude: le massif de l'Everest au Népal. J. Alpine 108-111. doi: 10.4000/rga.6759

Florea, L., Bird, B., Lau, J. K., Wang, L., Lei, Y., Yao, T., et al. (2017). Stable isotopes of river water and groundwater along altitudinal gradients in the high Himalayas and the eastern Nyainqentanghla mountains. J. Hydrol. Regional Stud. 14, 37-48. doi: 10.1016/j.ejrh.2017.10.003

Fujino, K., and Kato, K. (1978). "Determination ofoxygen isotopic concentration in the ground ice of a tundra area," in Joint Studies on Physical and Biological Environments in the Permafrost, Alaska and North Canada, July to August 1977, ed. S. Kinosita (Sapporo: The Institute of Low Temperature Science, Hokkaido University), 77-83.

Gardelle, J., Berthier, E., Arnaud, Y., and Kaab, A. (2013). Region-wide glacier mass balances over the Pamir-Karakoram-Himalaya during 1999-2011. Cryosphere 7, 1263-1286. doi: 10.5194/tc-7-1263-2013

Garzione, C. N., Quade, J., De Celles, P. G., and English, N. B. (2000). Predicting paleoelevation of Tibet and the Himalaya from $\Delta 18 \mathrm{O}$ vs altitude gradients in meteoric water across the Nepal Himalaya. Earth Planet Sci. Lett. 183, 215-229. doi: 10.1016/s0012-821x(00)00252-1

Ghezzi, L., Petrini, R., Montomoli, C., Carosi, R., Paudyal, K., and Cidu, R. (2017). Findings on water quality in Upper Mustang (Nepal) from a preliminary geochemical and geological survey. Environ. Earth Sci. 76:651. doi: 10.1007/ s12665-017-6991-0

Gonga-Saholiariliva, N., Neppel, L., Chevallier, P., François, D., and Savéan, M. (2016). geostatistical estimation of daily monsoon precipitation at fine spatial scale: koshi river basin. J. Hydrol. Eng. 21:05016017. doi: 10.1061/(ASCE)HE. 1943-5584.0001388

Guo, X., Tian, L., Wen, R., Yu, W., and Qu, D. (2017). Controls of precipitation $\triangle 18 \mathrm{O}$ on the northwestern tibetan plateau: a case study at ngari station. Atmos. Res. 189, 141-151. doi: 10.1016/j.atmosres.2017.02.004

He, S., and Richards, K. (2016). Stable isotopes in monsoon precipitation and water vapour in Nagqu, tibet, and their implications for monsoon moisture. J. Hydrol. 540, 615-622. doi: 10.1016/j.jhydrol.2016.06.046

Hodson, A., Porter, P., Lowe, A., and Mumford, P. (2002). Chemical denudation and silicate weathering in himalayan glacier basins: batura glacier, Pakistan. J. Hydrol. 262, 193-208. doi: 10.1016/S0022-1694(02)00 036-7

Immerzeel, W. W., van Beek, L. P. H., and Bierkens, M. F. P. (2010). Climate change will affect the asian water towers. Science 328, 1382-1385. doi: 10.1126/science. 1183188

Jacobi, H.-W., Lim, S., Ménégoz, M., Ginot, P., Laj, P., Bonasoni, P., et al. (2015). Black carbon in snow in the upper Himalayan Khumbu Valley, Nepal: observations and modeling of the impact on snow albedo, melting, and radiative forcing. Cryosphere 9, 1685-1699. doi: 10.5194/tc-9-16852015

Jacquemet, E. (2018). The Sherpa Community in the 'Yak Donald's' Era: Locational Struggles for Access to Resources in Mount Everest Touristic Region (Nepal). Ph.D. thesis, Université Michel de Montaigne - Bordeaux, Pessac.

Jeelani, G. (2008). Aquifer response to regional climate variability in a part of kashmir Himalaya in India. Hydrogeol. J. 16, 1625-1633. doi: 10.1007/s10040008-0335-9

Jeelani, G., Bhat, N. A., Shivanna, K., and Bhat, M. Y. (2011). Geochemical characterization of surface water and spring water in SE kashmir valley, western himalaya: implications to water-rock interaction. J. Earth Syst. Sci. 120, 921932. doi: 10.1007/s12040-011-0107-0

Jeelani, G., and Deshpande, R. D. (2017). Isotope fingerprinting of precipitation associated with western disturbances and Indian summer monsoons across the himalayas. J. Earth Syst. Sci. 126:108. doi: 10.1007/s12040-017-0894-z

Jeelani, G., Deshpande, R. D., Shah, R. A., and Hassan, W. (2017). Influence of southwest monsoons in the Kashmir valley, Western himalayas. Isotopes Environ. Health Stud. 53, 400-412. doi: 10.1080/10256016.2016.1273224

Jeelani, G., Saravana Kumar, U., and Kumar, B. (2013). Variation of $\Delta 18 \mathrm{O}$ and $\triangle \mathrm{D}$ in precipitation AND Stream waters across the Kashmir Himalaya (India) to distinguish and estimate the seasonal sources of stream flow. J. Hydrol. 481, 157-165. doi: 10.1016/j.jhydrol.2012.12.035

Jeelani, G., Shah, R. A., and Deshpande, R. D. (2018). Application of water Isotopes to Identify the sources of groundwater recharge in a karstified landscape of western himalaya. J. Clim. Change 4, 37-47. doi: 10.3233/jcc-180005
Jouzel, J., and Souchez, R. A. (1982). Melting andrefreezing at the glacier sole and the isotopic composition of the ice. J. Glaciol. 28, 35-42. doi: 10.3189/ s0022143000011771

Kaspari, S. D., Schwikowski, M., Gysel, M., Flanner, M. G., Kang, S., Hou, S., et al. (2011). Recent Increase in black carbon concentrations from a mt. Everest ice core spanning 1860-2000 AD. Geophys. Res. Lett. 38:L04703. doi: 10.1029/ $2010 \mathrm{gl} 1046096$

Kumar, A., Tiwari, S. K., Verma, A., and Gupta, A. K. (2018). Tracing isotopic signatures $(\Delta \mathrm{D}$ and $\Delta 18 \mathrm{O})$ in precipitation and glacier melt over chorabari glacier-hydroclimatic inferences for the upper ganga basin (UGB), Garhwal Himalaya. J. Hydrol. Regional Stud. 15, 68-89. doi: 10.1016/j.ejrh.2017.11.009

Lacelle, D. (2011). On the $\mathrm{d} 18 \mathrm{O}, \mathrm{dD}$ and D-excess relations in meteoric precipitation and during equilibrium freezing: theoretical approach and field examples. Permafrost Periglacial Process. 22, 13-25. doi: 10.1002/ ppp. 712

Lai, C. T., and Ehleringer, J. R. (2010). Deuterium excess reveals diurnal sources of water vapor in forest air. Oecologia 165, 213-223. doi: 10.1007/s00442-010$1721-2$

Li, L., and Garzione, C. N. (2017). Spatial distribution and controlling factors of stable isotopes in meteoric waters on the tibetan plateau: implications for paleoelevation reconstruction. Earth Planet. Sci. Lett. 460, 302-314. doi: 10. 1016/j.epsl.2016.11.046

Madhura, R. K., Krishnan, R., Revadekar, J. V., Mujumdar, M., and Goswami, B. N. (2015). Changes in western disturbances over the western himalayas in a warming environment. Clim. Dyn. 44, 1157-1168. doi: 10.1007/s00382-0142166-9

Manfredi, E. C., Flury, B., Viviano, G., Thakuri, S., Nath Khanal, S., Kumar Jha, P., et al. (2010). Solid waste and water quality management models for sagarmatha national park and buffer zone, Nepal. Implementation of a participatory modeling framework. Mountain Res. Dev. 30, 127-142. doi: 10. 1659/MRD-JOURNAL-D-10-00028.1

McDowell, G., Ford, J. D., Lehner, B., Berrang-Ford, L., and Sherpa, A. (2012) Climate-related hydrological change and human vulnerability in remote mountain regions: a case study from khumbu, Nepal. Regional Environ. Change 13, 299-310. doi: 10.1007/s10113-012-0333-2

Mimeau, L., Esteves, M., Jacobi, H.-W., and Zin, I. (2019). Evaluation of gridded and in situ precipitation datasets on modeled glacio-hydrologic response of a small glacierized himalayan catchment. J. Hydrometeorol. 20, 1103-1121. doi: 10.1175/JHM-D-18-0157.1

Nepal, S., Krause, P., Flügel, W.-A., Fink, M., and Fischer, C. (2014). Understanding the hydrological system dynamics of a glaciated alpine catchment in the himalayan region using the J2000 hydrological model. Hydrol. Process. 28, 1329-1344. doi: 10.1002/hyp.9627

Pisharoty, P. R., and Desai, B. N. (1956). Western disturbances and Indian weather. Indian J. Meteorol. Geophys. 8, 333-338.

Pörtner, H.-O., Roberts, D. C., Masson-Delmotte, V., Zhai, P., Tignor, M., Poloczanska, E., et al. (2019). IPCC Special Report on the Ocean and Cryosphere in a Changing Climate. Geneva: IPCC.

Puschiasis, O. (2015). Des Enjeux planétaires aux Perceptions Locales du Changement Climatique: Pratiques et discours au fil de l'eau chez les Sherpa de la vallée du Khumbu (Everest, Népal). Doctorat, Nanterre Université Paris Ouest Nanterre La Défense, Nanterre.

Puschiasis, O. (2019). Un vent de Changements Souffle sur l'Everest. Multiples Facettes de la Perception de la Météorologie et du climat chez les Sherpa. Available online at: http://www.ethnographiques.org/2019/Puschiasis (accessed August 10, 2020).

Ren, W., Yao, T., Xie, S., and He, Y. (2017). Controls on the stable isotopes in precipitation and surface waters across the southeastern tibetan plateau. J. Hydrol. 545, 276-287. doi: 10.1016/j.jhydrol.2016.12.034

Reynolds, R. C., and Johnson, N. M. (1972). Chemical weathering in temperate glacial environment of the Northern cascade mountains. Geochim. Cosmochim. Acta 36, 537-554. doi: 10.1016/0016-7037(72)90074-9

Rozanski, K., Araguas-Araguas, L., and Gonfiantini, R. (1993). "Isotopic patterns in modern global precipitation," in Climate Change in Continental Isotopic Records, 1-36. Geophysical Monograph 78, eds P. K. Swart, K. C. Lohmann, J. Mckenzie, and S. Savin (Washington, DC: American Geophysical Union).

Savéan, M., Delclaux, F., Chevallier, P., Wagnon, P., Gonga-Saholiariliva, N., Sharma, R., et al. (2015). Water budget on the dudh koshi river (Nepal): 
uncertainties on precipitation. J. Hydrol. 531, 850-862. doi: 10.1016/j.jhydrol. 2015.10.040

Searle, M. P., Simpson, R. L., Law, R. D., Parrish, R. R., and Waters, D. J. (2003). The structural geometry, metamorphic and magmatic evolution of the everest massif, high Himalaya of Nepal-south tibet. J. Geol. Soc. 160, 345-366. doi: 10.1144/0016-764902-126

Sevruk, B. (1989). "Reliability of precipitation measurements," in Not in File, ed. B. Sevruck (St Moriz: Swiss Federal Institute of Technology, Zurich), $13-19$.

Shea, J. M., Wagnon, P., Immerzeel, W. W., Biron, R., Brun, F., and Pellicciotti, F. (2015). A comparative high-altitude meteorological analysis from three catchments in the Nepalese himalaya. Int. J. Water Resour. Dev. 31, 174-200. doi: 10.1080/07900627.2015.1020417

Shen, H., and Poulsen, C. J. (2019). Precipitation $\delta^{18} \mathrm{O}$ on the himalaya-tibet orogeny and its relationship to surface elevation. Clim. Past 15, 169-187. doi: 10.5194/cp-15-169-2019

Singh, A. T., Rahaman, W., Sharma, P., Laluraj, C. M., Patel, L. K., Pratap, B., et al. (2019). Moisture sources for precipitation and hydrograph components of the sutri dhaka glacier basin, western himalayas. Water 11:2242. doi: 10.3390/ w11112242

Singh, K. A., and Hasnain, S. I. (1998). Major ion chemistry and weathering control in a high altitude basin: alaknanda river, garhwal himalaya, India. Hydrol. Sci. J. 43, 825-843. doi: 10.1080/02626669809492181

Spoon, J. (2011). The heterogeneity of khumbu sherpa ecological knowledge and understanding in sagarmatha (Mount Everest) national park and buffer zone, Nepal. Hum. Ecol. 39, 657-672. doi: 10.1007/s10745-0119424-9

Stuiver, M., Yang, I. C., and Denton, G. H. (1976). Permafrost oxygen isotope ratios and chronology of three cores from Antarctica. Nature 261, 547-550. doi: 10.1038/261547a0

Tahir, A. A., Chevallier, P., Arnaud, Y., Neppel, L., and Ahmad, B. (2011). Modeling snowmeltrunoff under climate scenarios in the Hunza River basin, Karakoram
Range, Northern Pakistan. J. Hydrol. 409, 104-117. doi: 10.1016/j.jhydrol.2011. 08.035

Turner, A. G., and Annamalai, H. (2012). Climate change and the south asian summer monsoon. Nat. Clim. Change 2, 587-595. doi: 10.1038/nclimate1495

Verma, A., Kumar, A., Gupta, A. K., Tiwari, S. K., Bhambri, R., and Naithani, S. (2018). Hydroclimatic significance of stable isotopes in precipitation from glaciers of garhwal himalaya, upper ganga basin (UGB), India. Hydrol. Process. 32, 1874-1893. doi: 10.1002/hyp.13128

Wang, B. (2006). The Asian Monsoon. Springer-Praxis Books in Environmental Sciences. Berlin: Springer.

Wen, R., Tian, L., Weng, Y., Liu, Z., and Zhao, Z. (2012). The altitude effect of $\Delta 18 \mathrm{O}$ in precipitation and river water in the southern himalayas. Chin. Sci. Bull. 57, 1693-1698. doi: 10.1007/s11434-012-4992-7

Wester, P., Mishra, A., Mukherji, A., and Shrestha, A. B. (eds). (2019). The Hindu Kush Himalaya Assessment. Mountains, Climate Change, Sustainability and People. ICIMOD. Kathmandu: Springer Nature. doi: 10.1007/978-3-319-92 288-1

Yao, T., Masson-Delmotte, V., Gao, J., Yu, W., Yang, X., Risi, C., et al. (2013). A review of climatic controls on $\Delta 18 \mathrm{O}$ in precipitation over the tibetan plateau: observations and simulations. Rev. Geophys. 51, 525-548. doi: 10.1002/rog. 20023

Conflict of Interest: The authors declare that the research was conducted in the absence of any commercial or financial relationships that could be construed as a potential conflict of interest.

Copyright (c) 2020 Chevallier, Seidel, Taupin and Puschiasis. This is an open-access article distributed under the terms of the Creative Commons Attribution License (CC BY). The use, distribution or reproduction in other forums is permitted, provided the original author(s) and the copyright owner(s) are credited and that the original publication in this journal is cited, in accordance with accepted academic practice. No use, distribution or reproduction is permitted which does not comply with these terms. 